\title{
ORGANIZATION AND TASKS OF INTERNAL AUDIT IN DOMESTIC AND FOREIGN BANKS IN SERBIA
}

\author{
Snezana Ljubisavljevic* \\ Faculty of Economics, University of Kragujevac, Kragujevac, Serbia
}

The paper attempts to determine the achieved level of internal audit development in Serbian banks, based on the referent Anglo-Saxon literature and practice. Empirical research has included the sample of 14 banks in the Republic of Serbia, out of the 32 banks, with the aim to seek the methods of organizing internal audit and its tasks within them. The subject of this study is to determine how managers and employees in senior positions in the bank understand the role and importance of internal audit. Based on the questionnaire responses, the aim of the paper is to make suggestions for the improvement of this important bank function. The research results indicate that the bank size does not affect the organization methods, responsibility, and tasks of the internal audit of the bank. The achieved level of internal audit development in financial institutions is at a much higher level compared to economic entities, but in many areas, it is behind the internal audit of developed countries.

Keywords: internal audit, organization, tasks, domestic banks, foreign banks

JEL Classification: M42, G21, H83

\section{INTRODUCTION}

Deregulation, information technology, and globalization are environmental factors that have especially influenced banking operations in recent years. Banking in the modern world is characterized by strong dynamics, which the term banking revolution is used for. In the conditions of the business volume growth and diversification of banking operations, the role and importance of internal audit increase. The bank seeks to establish an adequate internal controls system

\footnotetext{
* Correspondence to: S. Ljubisavljevic, Faculty of Economics, University of Kragujevac, D. Pucara 3, 34000 Kragujevac, Serbia; e-mail: ljubisavljevic@kg.ac.rs
}

to ensure well-regulated business operations and therefore achieve its goals. Internal audit ensures that internal controls quickly and accurately report on all completed transactions, as well as provide the proper protection of resources. Internal audit determines whether banks comply with laws and regulations, as well as whether the management takes appropriate measures to resolve weaknesses in such a control. The regular work of internal audit's organizational unit is to provide an independent assessment, testing, and an evaluation of the bank's activities. Société Générale Bank's 5-billion-euro worth of frauds and losses of at caused by its non-functioning internal controls system speaks about the importance of internal audit. Another example of the lack of internal controls is the case of 
Barings Bank, which failed to comply with procedures for the separation of duties.

Internal audit examines and evaluates the totality of the functioning of the entire business system and gives opinions and suggestions to improve its operations. The role of internal audit in the process of decision making stems from the fact that internal audit determines the reliability, reality and integrity of financial and business information coming from different organizational parts, and based on which appropriate business decisions are made at all management levels. It is a body of business management whose main tasks are: planning, organizing, disposition, coordination, and supervision. Internal audit is important because it plays a key role in preventing and detecting errors and illegal acts; it plays an important role in assessing and managing risks, thus protecting the safety of banking operations. The basic principles defined by the internal auditors' code of professional conduct are: independence and skepticism, then integrity, objectivity, confidentiality, and competence. The quality and usefulness of information determine the success of internal audit, while external audit assesses the effectiveness of internal audit. Internal audit protects a business system from the inside, protects the owner and the management from the negligent conduct of associates, simultaneously protecting the owner from the bank's management, and in the broadest sense, the interests of the public.

The paper deals with the general data on the banks in the RS, the organizational form of internal audit in the banks, its responsibility, i.e. subordination and tasks in the 14 banks. The main objective of this study is to empirically confirm the following main research hypotheses:

- The hypothesis 1 (H1): There is no statistically significant difference between the bank size and the organization of internal audit in the bank.

- The hypothesis 2 (H2): There is no statistically significant difference between the bank size and the assessment of the importance of internal audit's tasks.

- The hypothesis 3 (H3): There are no statistically significant differences between the arithmetic means of features (organization and tasks) and responses to all the questions among large, medium, and small banks in the population, i.e. the population is homogeneous in terms of the observed features, traits.

A scientific instrument used in this paper is a statistical methodology inclusive of a statistical description and a statistical analysis. The paper also includes general scientific methods, specific scientific methods, the processes of reasoning, and research methods. The specific data collection techniques or methods used in the paper are: case studies measurement, surveys, and interviews. The paper consists of five sections followed by a conclusion. The first section, after the Introduction, encompasses the historical emergence and development of internal audit as an important business function of every bank and other financial institutions. This is followed by an overview of the basic conclusions of previous scholars' research in the relevant scientific literature related to the subject of the research conducted in this paper. The second section discusses the tasks and functions of internal audit in the Serbian banks. Then, we present a description of the research methods used in the study, as well as the data that will be used in the research. The last section presents the conclusions of the survey divided into the following subsections: the basic information on the Serbian banks, internal audit organization in the Serbian banks, and internal audit tasks in the Serbian banks. The main results of the research are presented in the conclusion.

\section{INTERNAL AUDIT DEVELOPMENT AND LITERATURE REVIEW}

Internal audit is an additional control; as an internal mechanism, it usually acts post festum since it examines completed transactions. The global accounting literature has noted that both types of internal supervision (internal control and internal audit) occurred simultaneously. If we are talking about the first function segment of internal supervision, it must be taken into account that the current and subsequent control (internal audit) appear in handling the funds of the persons performing the collection of tax dues and certain financial transactions. There is reliable evidence 
that tax revenues in ancient Egypt were supervised by two separate persons. The first form of control was performed in the course of the work process, and the second - after its completion, in short and long intervals. These were, in fact, previous and subsequent controls - internal audit. The attribute "internal" comes from the fact that the person conducting a subsequent control was employed in a certain tax or budgetary institution. Clearly, then, there was no term "audit", which appeared much later, with the goal to adequately separate current and subsequent controls. The historical sources of internal auditing indicate that in ancient Greece there was a subsequent control of financial transactions in the state and other high-risk institutions. In this sense, the so-called "logisticians" in Athens back then reviewed accountants' business operations related to funds handling. This review was performed at regular intervals throughout the year and always at the end of the year. Considering the fact that the previous, current control was being performed during the year by the one giving orders, it is obvious that the aforementioned "logisticians" were the first audit clerks. The complex system of internal audit, as a form of control over internal controls, was developed in the famous Roman republic (Raschenberger, 1929). There is certain evidence of the origin of internal audit in Italy. Thus, the record on audit was found in the Italian city of Pisa in the year 831. The written sources indicate that internal audit functioned in some English cities as well in the year 1285. During the year 1299, the internal auditors of London were appointed for the purpose of reviewing the accounts of the royal property. Later, internal audit was increasingly being organized not only by the state institutions but also by larger entrepreneurs and banks (Stuart, 2012).

Internal audit development in the early development period ran quite slowly. There was an increasing need for it, because entrepreneurs did not have an opportunity and ability to immediately implement additional control. The main preoccupation of internal audit in this period was to examine the accuracy and timeliness of bookkeeping, as well as a possible abuse, fraud, and other forms of the appropriation of owners' property. Furthermore, the slow development of internal audit in the early developmental period was characterized by underdeveloped banking, entrepreneurship, small companies, and the like.
Bank development and an increase in the size of companies created a need for strengthening internal audit. In a contemporary business environment, the management of the business system is responsible for the successful operation of internal supervision. The business management is required to establish internal controls performed by all employees as part of their regular work duties and to supervise their operation. However, the management is preoccupied with current business activities, so they are unable to perform the direct supervision of the internal controls. To overcome this problem, the capital owner or another body approves the management the formation of a separate organizational unit of internal audit. Internal audit has been developing simultaneously with the increasing complexity of the business system management. This development is basically divided into two periods; the period to the onset and the end of the Great Depression, which lasted from 1929 to 1933, and the period of prosperity after the aforementioned Great Depression. The development of contemporary internal audit began in the mid-nineteenth century, with the formation of the first auditing organizational units in major capitalist enterprises and banks in the organizational form of the sector, service, or department of internal audit (Milojević, 2006).

The first organizational units of internal audit in the United States began to form in 1864 . However, internal audit in the US received a special developmental trend in 1942, when the Institute of Internal Auditors was founded. The newly-formed Institute had a strong influence on the development of internal audit in the world. Thus, 25 years later, it included members from all the continents. During the year 1947, the US made another significant move in the strengthening and further development of internal audit. The Institute of Internal Auditors issued and published a Statement on Internal Auditors' Duties and Responsibilities, thereby defining their position more completely. The Statement represents the first step towards developing standards for the professional practice of internal auditing (Poznanić, 2011). The first internal audit department in Germany was established in 1875, which, at the same time, was the first organization of internal audit in Europe. The decision on the establishment of this organizational unit was made by the Board of Trustees of the famous Krupp company. The scope of the work 
of this internal audit department was not confined to the supervision of accounting, but also included some other vital activities, such as accomplishing plans, compliance with regulations, contracts, instructions for the work, and the like. Following the example of the United States, the Institute of Internal Audit in Germany was established in 1958, whose aims were the same as those of the US Institute of Internal Auditors (Picket, 2011).

The introduction of internal audit in France occurred much later than in the US and Germany. The specific system of supervision by the so-called government commissioners and state controllers contributed to the slower development of internal and external audit. In France in the nineteen-sixties, the development of internal and external audit in firms and banks that foreign entities invested their capital in was intensified. From that time on, the number of internal auditors began to increase, which directly influenced the establishment of the French Association of Internal Auditors in 1965, which grew into the French Institute of Internal Auditors in 1973.

The practice of internal auditing from developed countries is spreading in all countries of the world.

As for the theoretical framework of internal auditing, we shall list some of the most important definitions of internal audit that include the purpose, goal and tasks of this function. In the nineteen-nineties, a prominent audit theoretician, Tom Lee, defined audit as follows: "In the broadest sense of the word, audit is a means by which a person is assured by another person in the quality, condition, or status of an issue questioned by such other person; the need for audit arises because the person is in doubt or suspicion in the quality, condition, or status of the underlying issues, and is not personally able to eliminate the suspicion or doubt" (Lee \& Alan, 1984, 213). The task of internal audit is to explore, examine, and evaluate the internal controls system and its effectiveness in the activities of each business system, to report on findings and propose solutions to the management (Meigs, Whittinfton \& Pany, 1988). Internal audit examines the organization and functioning of the accounting system and related internal controls and the accuracy of financial and operational information, evaluates the costeffectiveness, efficiency and effectiveness of business operations and controls as well as the implementation of policies, plans, and procedures.

Not only are audit and audit work unique to economic earning, but their application is much broader, as $\mathrm{S}$. Kukoleča points out in the following definition: "Any systemic and thoroughly performed subsequent control of an organization's operations or the audit of the financial operation includes a detailed examination of the entire business operation or an examination of a narrow sector; it is performed when it is necessary to precisely illuminate the true state, when there is suspicion of financial abuse, or when managing bodies need it for some special reasons" (Kukoleča, 1995, 131). The American Institute of Chartered Public Accountants - AICPA defined audit as a systematic process of objective collecting and evaluating evidence on assertions related to economic actions and events, to the confidence level of the correspondence of those assertions and the established criteria as well as an announcement of the results to the interested user.

G. Vinten highlights the fact that internal audit is a continuing and extensive research of seemingly good organizations with an aim of gaining an insight into the real situation or the position of the organization and its environment, in order to achieve better control over future operations (Picket, 1997). Unlike all previous definitions of internal audit, this one emphasizes a need for internal audit to direct itself towards the improvement of future business operations, not merely to the review of past events.

Internal auditing is an effective instrument of managerial control. Although it is often limited to the auditing of accounts, within its field of work, it is related to the evaluation of the business as a whole (Munro \& Stewart, 2011). Thus, internal auditors, in an attempt to authenticate documents, also evaluate the policies, procedures and quality of decision making and the management, the effectiveness of methods and procedures, and other specific business problems (Krogstad, Ridley \& Ritterbeg, 1999).

The internal audit of a bank is defined as "an independent management function which involves a constant and critical evaluation of the bank in order to give suggestions for its improvement, create value and strengthen the overall governance mechanism, 
including risk management of the entity and internal control system" (Rossel, 2007, 18). The task of the internal audit is to "investigate, examine, and evaluate the system of internal controls and their effectiveness in the activities of each separate part of the business, to report on the findings and propose solutions to management" (Allen, Sneathen \& Tim 2007, 156). The Internal audit sector assists an organization in carrying out its goals and its adopted policies in a systematic and disciplined manner, through evaluations and the effectiveness improvement of risk assessment, management control, and the system of managing processes in the bank (Renard, 1997). According to R. Moeller, internal audit is an independent assessment of business functions established in an organization with the goal to examine and evaluate its activities; therefore it is a service provided to that organization (Boynton \& Johnson, 2006).

In the professional practice, internal audit is defined as "the activity of an independent, objective assurance and a consulting activity designed with the goal to create added value and improve banking operations" (Spahić, 2008, 11).

J. Morris, president of the Institute of Internal Auditors UK, made the following statement: "There is no doubt that the internal audit professionals in the UK play a big role in helping managers in maintaining internal control." Then, he concludes that internal audit is becoming a function consisting of various business activities and expanding both in the management process and in the research and development of banks. G. Vinten points out "that the internal audit is continuing and extensive research of seemingly good organizations with the goal of gaining an insight into the real situation or position of the bank and its environment, in order to achieve better control over future operations" (Gramling, Rittenberg \& Johnstone, 2012, 972).

From these definitions, it follows that internal audit is a consulting activity which, in addition to its regular tasks, enables the creation of the added value of the bank, or the shareholder value added. In the bank, organized in a modern manner, internal auditors can play a key role in detecting and preventing illegal acts. Fraud and unauthorized activities include an illegal acts area, characterized by intentional deception or fraud. They can be made in favor of or against the bank, by entities employed by the bank or by external entities. The assessment of the bank's compliance with the law, business practices and management activities is therefore an important task of internal audit. For this purpose, internal auditors evaluate the effectiveness of the accounting system and internal controls system in the bank (Soh \& Martinov-Bennie, 2011). Finally, the role of internal audit consists of the impact on the timely preparation of financial statements and contributes to the corporate governance of the bank in general (Ljubisavljević, 2000).

\section{INTERNAL AUDIT FUNCTIONS IN BANKS IN SERBIA}

According to the Law on Banks and Other Financial Institutions (The Official Gazette of the Republic of Serbia, No. 107/2005), and the amendments to the Law (The Official Gazette of the Republic of Serbia, No. 91/2010), the following areas of internal control and audit are defined:

- internal control,

- bank's compliance function,

- the internal audit function,

- the powers of internal audit, and

- the annual report on the adequacy of risk management and internal control.

Pursuant to this law, inside (internal) audit and the committee on banking supervision control the regularities of the banks in the RS and the efficiency of the functioning of the internal controls system. The main task of internal audit's organizational unit is to provide a bank's board with an independent and objective opinion on issues subject to audit. Internal audit performs an advisory activity aimed at improving the existing internal controls system (Sarens \& De Beelde, 2006), and assists the bank's board in achieving its objectives. Internal audit performs all of the above by applying a systematic, disciplined, and documented approach to the evaluation and improvement of the existing methods of managing risks, control, and governance processes. In accordance with these responsibilities, the law defines the following internal audit functions: 
- The evaluation of the adequacy and reliability of the bank's internal controls system and the control functions of the bank's compliance;

- Ensuring that risks are adequately identified and controlled;

- Determining weaknesses of the bank's operations and its employees, as well as the cases of default and excess of powers, preparing proposals to eliminate these weaknesses, and recommendations for their prevention;

- Holding meetings with the bank's board, and the committee on banking supervision, and

- The regular preparation of reports on internal audit activities and their submission to the board of directors and the committee on banking supervision.

For these functions, internal audit must be organized as a separate organizational unit of the bank. The bank is obliged to arrange and implement the procedures of the internal controls system in a manner allowing the continuous monitoring and measurement of risks that could adversely affect the achievement of the bank's established business goals, such as: credit risk, country risk, foreign exchange risk, market risk, interest rate risk, liquidity risk, operational risk, and other risks. The bank is required to develop the internal controls system in a manner allowing its timely assessment of the existing and new risks, including risks not previously controlled, and those beyond the control of the bank (external risks), and the control of risks which will keep negatively impacting the bank's operations and solvency to a minimum. The control of the bank's compliance is within the scope of the activities of an organizational unit of the bank.

The head of this unit is responsible for identifying and monitoring the compliance risks as well as for managing risk, especially including the risk of sanctions of the regulatory body and financial losses, as well as reputational risk. The compliance risk arises due to a lack of compliance with the laws and other regulations, operating standards, procedures on preventing money laundering, as well as other acts governing banking operations. Bank employees are required to provide this organizational unit with an access to the documents and information they possess.
The organizational unit, with the control of the bank's compliance within its scope of activities, is required to identify and assess the key risks of compliance and propose plans for managing those risks, and reports on this, at least once a year. This organizational unit is obliged to draw up a program for monitoring the bank's compliance, which contains the methodology of the organizational unit, its planned activities, the methods and deadlines of the report preparation, the methods of verifying such compliance, and a staff training plan. As regards internal audit, the head of the internal audit creates a program of internal audit and establishes the methodology of its activities, especially a manual for internal audit activities, the methods and deadlines for the preparation and submission of internal audit reports to the competent authorities of the bank, the methods of monitoring the recommended activities for eliminating irregularities and deficiencies in the bank, and the method and responsibility for the creation, usage, and maintenance of the documentation of internal audit activities according to the annual plan. The head of internal audit's organizational unit is responsible for the efficient, continuous, regular, and quality performance of the internal audit function and the effective implementation of the programs and annual operational plans of such audit. As for the powers of internal audit, the employees in the organizational unit have the right to access all the documents of the bank and its subsidiaries, as well as to the same of the members of the same banking group, in order to supervise banking operation without restrictions. Internal auditors attend meetings of the bank's board of directors. The annual report on the adequacy of risk management and internal control of banks is submitted together with annual financial statements.

The law defines the functions and tasks of the committee on banking supervision, internal audit, internal control functions, their relationship and the relationship with other bodies: the board of directors, the bank's assembly, and the executive committee. The committee on banking supervision controls the regularity of the bank and monitors the internal controls system. This function is performed by the bank's internal audit, while the head of the internal audit reports to the committee. While internal control is present in all organizational units and is built into 
the organizational structure of the bank, the audit assesses the effectiveness of the internal controls system and is organized as a separate unit of the bank. The board of directors appoints and dismisses the head of the organizational unit, within whose scope of activities the control of the bank's compliance is. Also, the board of directors elects and dismisses the head of the organizational unit within whose scope of activities internal audit is. The internal audit organizational unit reports on its activities to the bank's board of directors. Finally, the board approves the annual report on the adequacy of risk management and the internal control of the bank. The assembly of the Bank is informed by the head of internal audit on the convening of the meetings of the committee on banking supervision and on the cancelation of the scheduled meeting. The executive committee adopts the report prepared by the organizational unit, which encompasses the control of the bank's compliance. The executive committee and the committee on banking supervision are notified by the head of the organizational unit, which encompasses the control of the bank's compliance, on the identified omissions related to such compliance. Members of the bank's executive committee are responsible for the performance of internal control in it. The bank is obliged to submit an annual report to the National Bank of Serbia on the adequacy of the risk management and internal control of the bank. The contents of this annual report and its submission deadlines are prescribed by the National Bank of Serbia, and such a report must contain the following statements:

- Whether the board of directors and the executive committee have identified significant risks;

- Whether the policies of internal control and risk management are adequate and whether they are effectively implemented;

- Whether an accurate representation of the policies of risk management and internal controls system is submitted to the National Bank of Serbia;

- That the plan of the activities for eliminating deficiencies is establish and applied, or that it will be established and submitted to the board of the bank for approval.

In addition to the Law on Banks and Other Financial Institutions, the governor of the National Bank of Yugoslavia adopted the Decision on the basic principles of the organization and operation of the internal audit of banks and other financial institutions (The Official Gazette of the FRY, No. 39/2002), laying down the basic objectives of internal audit, thus providing the protection of banks' solvency and an accurate presentation of their financial results. This decision also defines:

- The independence of the internal auditor from the bank director and entities with special powers and responsibilities in the bank;

- That the internal auditor must not perform management tasks in the bank;

- The independence of the internal auditor when deciding on the selection of a method and the manners of its application;

- That the bank is obliged to perform the internal audit function in accordance with the internationally recognized standards of internal auditing and the auditing of banks;

- The responsibilities of the board of directors regarding the bank's acts (the adoption of the program and the annual operational audit plan and the conditions for their implementation, the appointment of the internal auditor and determining the amount of their income, etc.);

- The commitment of the internal auditor to report to the supervisory committee, the bank director, and the persons with special powers and responsibilities in the bank, responsible for eliminating the irregularities and deficiencies;

- The frequency of audit, which should be increased in the banking areas with a higher risk degree;

- That the director and the persons with special powers and responsibilities in the bank shall be responsible for accepting or rejecting the internal auditor's suggestions, and whether irregularities and deficiencies in the bank are effectively eliminated.

From the above regulations, it remains unclear whether internal auditors submit their statements made in the audit report to the board of directors, the supervisory committee, or the bank's management. The empirical research has just shown that internal audit in banks in the RS is subordinate to the various bodies of the bank. 


\section{RESEARCH METHODOLOGY}

The survey includes 14 banks in the Republic of Serbia, with the aim to seek the methods of the organization and tasks of internal audit. The research was conducted in the first quarter of 2011, using the cross-sectional study - a survey. The empirical research includes all the activities from the beginning of the data collection, through the questionnaires, to the application of the research results in practice. The structure of the research consisted of (Milosavljević \& Radosavljević, 2003):

- A pre-investigation, with the project reconstruction, on the research project and assistants, the phenomenon itself, and the research subject, if necessary;

- The collecting, sorting, grouping and processing of the data for the purpose of the empirical research (the methods of a statistical description);

- A data analysis (a statistical analysis);

- The conclusion and presentation of the research results based on the quantitatively derived conclusions, and

- The recommendations on the use of the research results in practice.

We have used general scientific methods in the paper (the statistical, modeling, and analytical and deductive methods), as well as specific research methods, the processes of reasoning, the methods of research, i.e. the data collection techniques available to the researcher during the research (the analytical and synthetic method, systemic thinking, abstractionconcretization, generalization-specification, classification, and induction-deduction). The special data collection techniques or methods used in the paper are: a scientific observation, methods for cause research, the content analysis, the survey and the interview. The most prevalent techniques and analysis methods in the paper are the survey, the statistical method, and the content analysis. The variables in the survey are large, medium, and small banks, the tasks of internal audit in banks classified into six groups, the organization of internal audit in banks, and the ratings of the responses of the 14 banks surveyed concerning the internal audit tasks and the methods of organizing internal audit in these banks.
As for the subsets and the sample, the survey was conducted in 14 elementary units, out of which 5 are large banks, 5 medium banks, and 4 small banks. The survey covers all the large and medium banks, which means that these are two subsets, strata. As regards small banks, the survey can be concluded to have been conducted on the simple random sample of the four elementary units. The survey was completed by the internal audit executives and managers at the other business levels in the bank. As for the description of the measuring instrument, the questionnaire consists of the two main parts. At the beginning of the survey, the banks list the basic information grouped into 6 questions. The second part of the questionnaire consists of the 7 questions regarding the method of organizing internal audit in the banks and the internal audit tasks in the banks. Depending on the questions and responses, the scales differ and range from: 1-3 (the bank size, the bank's organization, and membership on the external or internal body of the bank) and 1-5 (the subordination of the internal auditor and the rating of the internal audit tasks). All the data on the surveyed banks are saved in a Microsoft Excel 2007 database. The statistical data analysis was performed using the method of a statistical description: the data were collected, grouped and displayed using circle graphs.

\section{RESEARCH RESULTS}

\section{Basic data on banks}

The data were grouped into the following six questions: Name, location, and the origin country of a bank; domestic or foreign bank; bank's organizational form (head office, subsidiary, representative office of the foreign bank), subsidiary/representative office, district; banking group or holding; total employees number, total income and total assets in 2011.

The banks unwilling to fill out the questionnaires explained that the reasons for this were their lack of time and secrecy. Out of the total number of the banks, $64 \%$ are the banks with foreign capital, while $36 \%$ are domestic banks, which is accounted for in Table 1 . The criterion of the total revenues in 2011 was taken for the ranking of the banks as large, medium, and small. 
Table 1 Ranking of banks from the sample

\begin{tabular}{clcrr}
\hline No & Bank & Employees Number & Total assets & Total revenue \\
\hline 1 & Banca Intesa & 3116 & 359.123 .000 .000 & 58.296 .611 .000 \\
2 & Raiffeisen Bank & 2000 & 178.833 .012 .000 & 36.397 .803 .000 \\
3 & Komercijalna Banka & 3105 & 255.868 .309 .000 & 28.683 .475 .000 \\
4 & Societe Generale Bank & 1300 & 163.433 .939 .000 & 18.723 .903 .000 \\
5 & Aik Banka & 478 & 141.583 .427 .000 & 14.890 .254 .000 \\
6 & ProCredit Bank & 2000 & 69.671 .964 .000 & 12.965 .608 .000 \\
7 & Vojvođanska Banka & 2589 & 87.112 .877 .000 & 10.187 .080 .000 \\
8 & Univerzal Banka & 500 & 35.055 .548 .000 & 5.453 .077 .000 \\
9 & KBC Banka & 611 & 29.068 .855 .000 & 4.275 .489 .000 \\
10 & Čačanska Banka & 387 & 28.673 .216 .000 & 4.070 .348 .000 \\
11 & Findomestic Banka & 460 & 18.586 .544 .000 & 3.471 .556 .000 \\
12 & Credit Agricole Banka & 959 & 34.156 .354 .000 & 1.700 .173 .000 \\
13 & Credy Banka & 390 & 10.935 .176 .000 & 1.180 .818 .000 \\
14 & Alpha Bank & 1538 & 98.370 .114 .000 & 1.068 .279 .000 \\
\hline
\end{tabular}

Source: Author, according to the data from the survey

\section{Organizing internal audit in banks}

Based on the research conducted by the direct fillingout of the questionnaire on the organization of internal audit in banks, the following results have been obtained.

In all of the 14 banks (100\% surveyed), internal audit is organized as an independent organizational unit and the internal auditor is an independent entity, as defined under the Law on Banks. Internal audit can be organized as a sector, department, or service, which primarily depends on the bank size. Internal audit is organized as a sector in the following banks: Univerzal Banka, Banca Intesa, Komercijalna Banka, Findomestic Banka, Alpha Bank, and Vojvođanska Banka. Internal audit is organized as a department in the following banks: Credit Agricole Banka, Societe Generale Bank, Raiffeisen Bank, KBC Banka, and Credy Banka. Internal audit is organized as a service in AIK Banka, ProCredit Bank, and Čačanska Banka.

Internal audit is hierarchically subordinate to the board of directors in the following banks: Credit Agricole Banka, Čačanska Banka, Findomestic Banka, and ProCredit Bank. Internal audit is subordinate to the bank's management in: Banca Intesa, Societe
Generale Bank, Raiffeisen Bank, and Vojvodjanska Banka. Internal Audit is subordinate to the executive committee in: KBC Banka, AIK Banka, and Credy Banka. Internal audit is subordinate to the audit committee in the following banks: Alpha Bank and Komercijalna Banka. Univerzal Banka is the only one to have responded that internal auditors are subordinate to the shareholders' assembly.

Based on the above, and illustrated in Graph 1, it can be concluded that internal audit is organized as a:

- sector in 6 banks, which is $42.86 \%$ of the respondents,

- service in 3 banks, which is $21.43 \%$ of the respondents, and

- department in 5 banks, which accounts for 35.71\% of the banks surveyed.

As for the organization of internal audit in the RS, it can be concluded that, in the majority of the banks, it is organized as a sector, then as a department, while the smallest number of the banks organized their internal audit as a service.

As Graph 2 displays, internal audit is subordinate, i.e. responsible, to: 


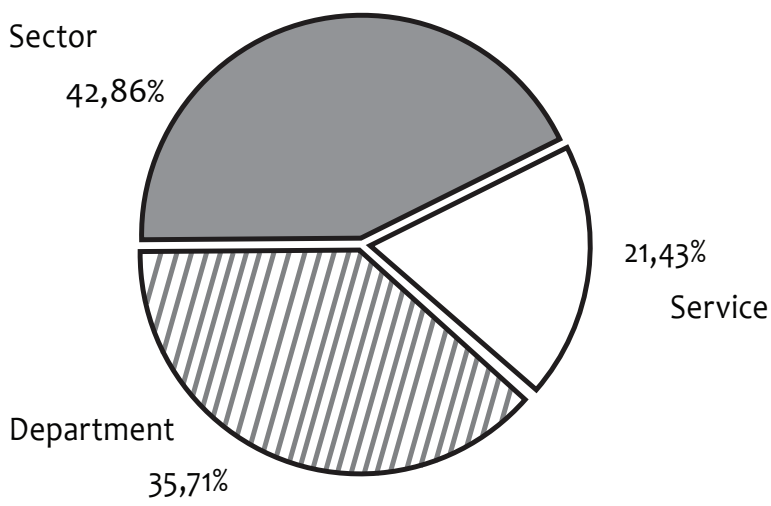

Graph 1 Organization of internal audit in banks

Source: Author, according to the data from the survey

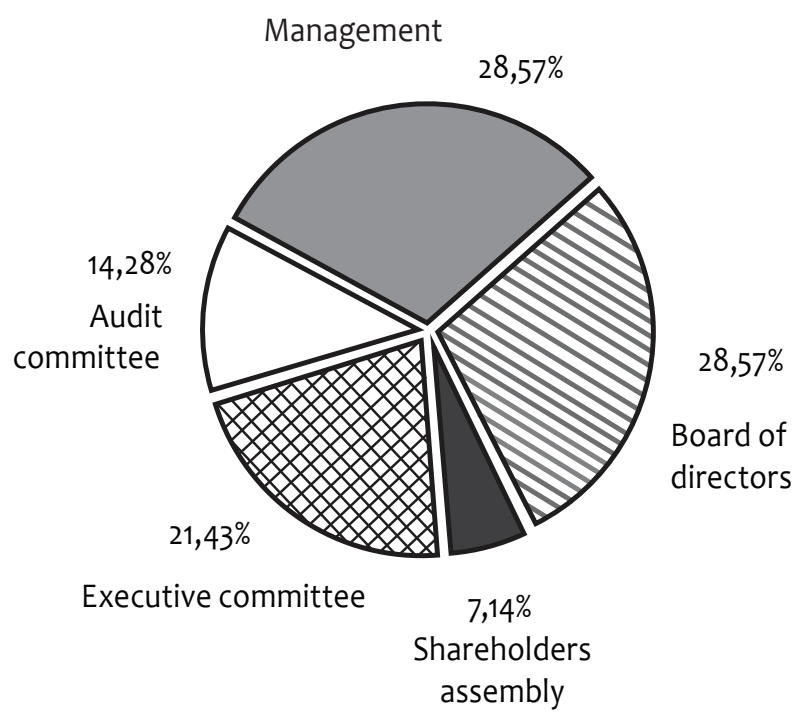

Graph 2 Subordination of internal audit

Source: Author, according to the data from the survey

- the management of the bank, in 4 banks, which is $28.57 \%$ of the respondents,

- the board of directors, in 4 banks, which is $28.57 \%$ of the respondents,

- the executive committee, in 3 banks, which is $21.43 \%$ of the respondents,
- the audit committee, in 2 banks, which is $14.28 \%$ of the respondents, and

- the shareholders' assembly, in 1 bank, which represents $7.14 \%$ of the respondents

Internal audit in the banks in the RS is usually subordinate to the board of directors and the management of the bank, whereas a smaller number of banks subordinated their internal audit to the executive committee, the audit committee, and the shareholders' assembly of the bank.

\section{The tasks of the internal audit in banks}

Based on the research conducted, by filling in the questionnaire on the tasks of internal audit in banks, we have obtained the following results:

- Ten banks, i.e. $71.43 \%$ of the respondents, completely agreed that the assessment of the bank's compliance with the law, policies, and business practice of the bank was a task of internal audit, giving a rating of 5 , which leads to the conclusion that this is the primary task of internal audit in the RS;

- Four banks, i.e. $28.57 \%$ of the respondents gave a rating of 4 , which means that they agreed with it, which is presented by Graph 3.

The presented graph clearly shows that the primary task of internal audit in the banks in the RS is the assessment of the bank's compliance with the law, policies, and business practice of the bank.

Graph 4 displays how the bank managers ranked the task of internal audit related to the performance evaluation of the accounting systems and the internal controls system.

Five banks, i.e. $35.71 \%$ of the respondents, completely agreed that the task of internal audit was the assessment of the effectiveness of the accounting system and the internal controls system and gave a rating of 5; five banks, namely $35.71 \%$ of the respondents, gave a rating of 4 , which means they agreed with this; two banks, i.e. $14.28 \%$ of the respondents, gave a rating of 3 , which means they could not decide if this was the task of internal audit; two banks, i.e. $14.28 \%$ of the 


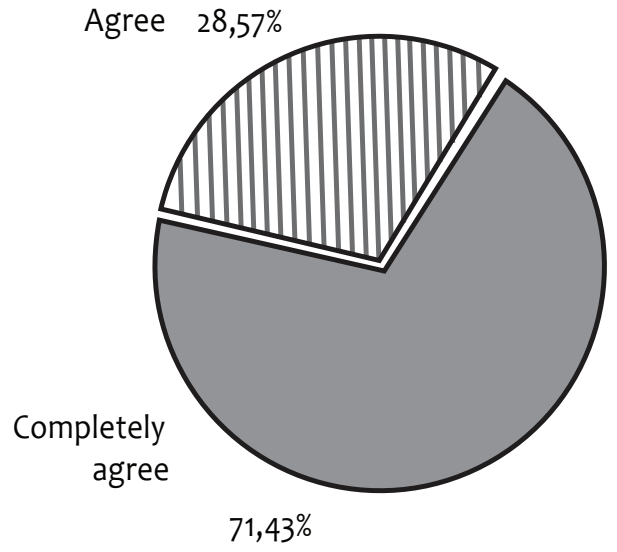

Graph 3 The assessment of the bank's compliance with the law, policies, and business practice of the bank

Source: Author, according to the data from the survey

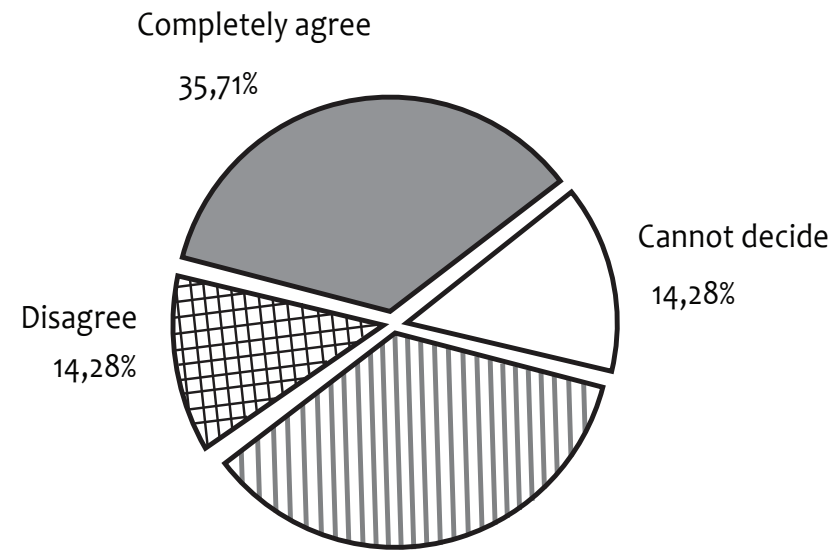

$35,71 \%$

Agree

Graph 4 The assessment of the effectiveness of the accounting system and the internal controls system

Source: Author, according to the data from the survey

respondents, gave a rating of 2, which means they disagreed that this was the task of internal audit.

The majority of the banks in the RS understand that the primary task of internal audit is the assessment of the effectiveness of the accounting system and the internal controls system. More than $70 \%$ of the banks agree or completely agree that the assessment of the effectiveness of the accounting system and the internal controls system is the primary task of the internal audit.

Graph 5 shows that detecting and preventing errors and illegal acts is an important task of internal audit in the banks in Serbia.

Twelve banks, i.e. $85.71 \%$ of the respondents, completely agreed that detecting and preventing errors and illegal acts was the task of internal audit, giving it a rating of 5; one bank, i.e. $7.14 \%$ of the respondents, could not decide whether this was the task of internal audit and gave a rating of 3; one bank, i.e. $7.14 \%$ of the respondents, disagreed that this was the task of internal audit, and gave a rating of 2 .

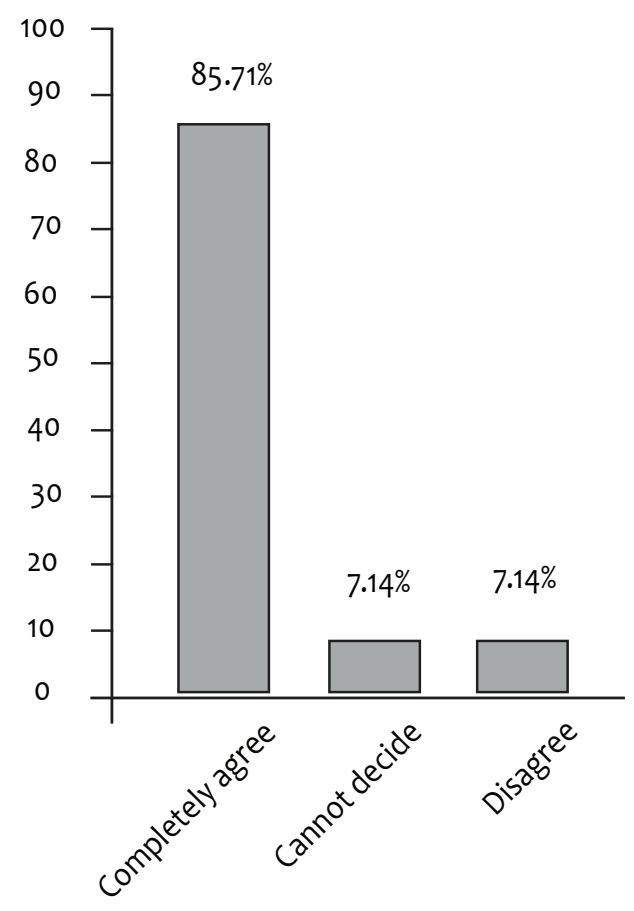

Graph 5 Detecting and preventing errors and illegal acts

Source: Author, according to the data from the survey 
Graph 6 illustrates how the bank managers in the RS responded to the question of whether they believed the timely preparation of quality financial statements was a significant task of the internal audit organizational unit in the banks in the RS.

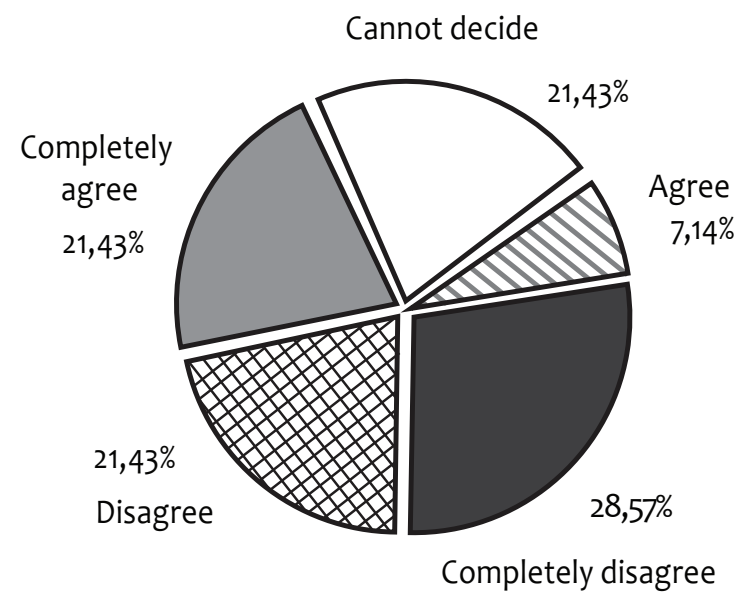

Graph 6 The timely preparation of quality financial statements

Source: Author, according to the data from the survey

Three banks, i.e. $21.43 \%$ of the respondents, completely agreed that the timely preparation of quality financial statements was internal audit's task and gave a rating of 5 ; one bank, that is $7.14 \%$ of the respondents, gave the rating of 4 , which means that they agreed with this; three banks, i.e. $21.43 \%$ of the respondents, could not decide whether this was a task of internal audit and gave a rating of 3 ; three banks, i.e. $21.43 \%$ of the respondents, disagreed that this was a task of internal audit and gave a rating of 2; four banks, namely $28.57 \%$ of the respondents completely disagreed that this was the task of internal audit and gave a rating of 1 .

Graph 7 shows how the banks responded to the question of whether the shareholder value added is a significant task of the internal audit of the bank.

One bank, i.e. $7.14 \%$ of the respondents, completely agreed that the shareholder value added was a task of internal audit and gave a rating of 5; two banks, i.e.
$14.28 \%$ of the respondents, gave a rating of 4 , which means that they agreed with this; five banks, namely $35.71 \%$ of the respondents, could not decide whether this was a task of internal audit and gave a rating of 3 ; two banks, i.e. $14.28 \%$ of the respondents, disagreed that this was a task of internal audit and gave a rating of 2; four banks, namely $28.57 \%$ of the respondents, completely disagreed that this was the task of internal audit and gave a rating of 1 .

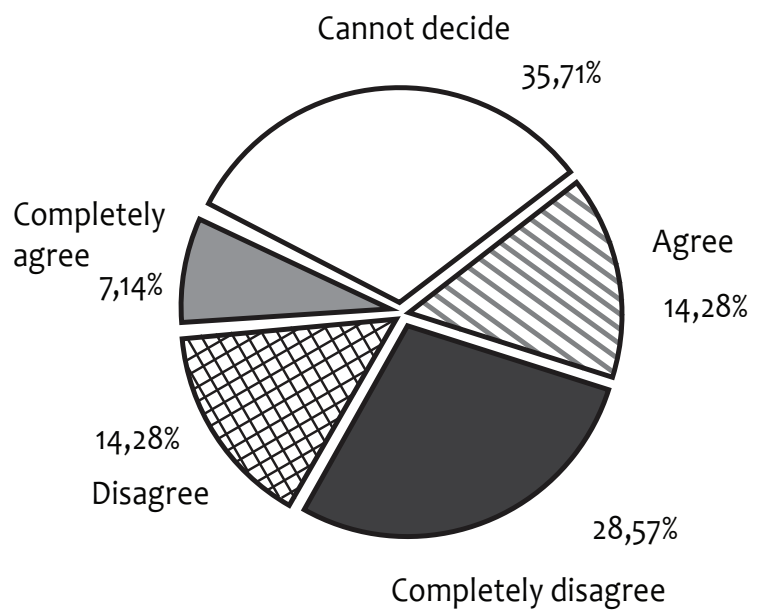

Grafikon 7 Shareholder value added

Source: Author, according to the data from the survey

Having conducted this research, we have demonstrated all the three research hypotheses. The bank size does not affect the organization and tasks of internal audit, which means that there is the homogeneity of the population.

\section{CONCLUSION}

The development of internal audit as a tool of business decision making is a result of today's turbulent and complex business conditions. The conditions of the rapid development of techniques, technologies, growing competition, globalization, the diversification and decentralization of banks have influenced 
significant changes in decision making. This leads to the prominent role and importance of planning, organizing and control at all hierarchical levels.

Based on the questionnaires and the variety of the responses, a conclusion can be drawn that internal audit in the banks in the RS still has an unclear context. The world experience is not better and shows that about $73 \%$ of internal audit services have been existing for less than 20 years, so we can explain why many banks have not had enough time to adapt to the tasks of internal audit and completely understand them. The survey that was conducted in the 14 banks in Serbia has showed the following:

- Foreign banks are dominant in the Republic of Serbia (64\%);

- The head offices were surveyed the most $(54 \%)$, afterwards the subsidiaries (39\%), and the branches $(7 \%) ;$

- Banca Intesa is the largest bank in the Republic of Serbia, according to most of the criteria;

- Internal audit in the banks surveyed is equally organized as a sector $(43 \%)$, service $(21 \%)$, or department (36\%), which is not always in correlation with the bank size;

- $29 \%$ of the banks in the RS consider internal audit to be subordinate to the board of directors, and

- The primary task of the banks is an assessment of the bank's compliance with the law, policies, business practice, and management activities.

Based on the conclusions drawn from the empirical research, we can form suggestions for the improvement of the internal audit function in the banks in Serbia. The task of internal audit should be to study the plans, programs, policies, and procedures in order to objectively evaluate their performance at all levels. Also, the task of internal audit should include the critical monitoring of the overall plan achievement as well as individual plans, informing the management on any deviations from the standards and the planned objectives, giving recommendations and advice on possible corrective actions to eliminate the detected discrepancies. Internal audit should increasingly be directed towards the anticipation of potential risks in the bank's certain areas and advising the management on a possibility of managing many risks by designing and supervising an appropriate internal controls system that will effectively reduce risks. Therefore, the entire business operations directed to the future should be the object of the investigation of the internal auditor. A degree which new tasks of internal audit are accomplished to and the effectiveness of the implementation of the policies and procedures in the future practice of Serbia's banking operations can be inspiring for some future research on the functioning of this extremely important area of banking operations.

Based on the research conducted in the banks in the Republic of Serbia, it can be concluded that internal audit was organized as an independent organizational unit, as a sector, in most of the surveyed banks. The decision on the basic principles of the organization and operation of internal audit in banks stipulates that internal audit should be organized as an independent organizational unit, since in this way, internal audit continuously monitors, checks and improves the system of functioning in the bank, identifies risks the bank is or can be exposed to, evaluates the established internal controls system, and issues appropriate recommendations for removing irregularities. This provides the basic objective of internal audit to be accomplished, which is to ensure the protection of the bank's solvency and to realistically show its financial results.

The research has shown that internal audit in the banks in Serbia is subordinate to the board of directors and the bank management, i.e. this is the case in most of the surveyed banks. Given the fact that in the contemporary business conditions in the world , there is an opinion that it is the best for internal audit to be subjected to the top management. In our country, the banks partially fulfill this requirement, because, in addition to such subordination to the board, there is also internal audit's subordination to the bank management. Only a small number of the banks surveyed relate subordination of internal audit to the executive committee and the audit committee. The subordination of internal audit to the bank's shareholder assembly, as the top management, occurs in a very small number of the banks in our country. In order to meet the world-class business, the system of the subordination of internal audit to the audit 
committee must be improved in all the banks, in the whole country, especially in the large banks.

As for the tasks of internal audit, the banks in our country believe that these are the detection and prevention of errors and illegal acts, the assessment of the bank's compliance with the law, policies, and business practice of the bank. Other tasks: the assessment of the effectiveness of the accounting system and the internal controls system, the timely preparation of quality financial reports, and shareholder value added were rated lower by our banks. Since they are not sufficiently familiar with them, the banks feel that these tasks of internal audit are not that important; in the world, however, these tasks are very well-developed. Therefore, we have to try to get a clearer understanding of them and further educate ourselves. It can be concluded that internal audit is in fact the management's advisor and that the work of internal audit is a responsible one as it relates to the provision of advice and making suggestions and as such cannot be deprived of its independence. Thus, internal audit in banks is an important function that has strongly been expanding in recent years.

It is interesting to note that internal audit will include more new and diverse domains, namely: quality audit, environmental audit, entrepreneurial audit, management audit, strategy audit, and the like. One thing is certain - internal audit has become an internal advisor with a protective character instead of a repressive one. Internal audit is a universal activity that can be applied to all banks and in all segments of a bank. Therefore, internal audit is a function controlling all other functions.

\section{REFERENCES}

Allen, D., Sneathen D., \& Tim, K. (2007). The Effects of Fraud and Going-concern Risk on Auditors' Assessments of the Risk of Material Misstatement and Resulting Audit Procedures, International Journal of Auditing, 11(3), 149-163.

Boynton W., \& Johnson, R. (2006). Modern Auditing. The $8^{\text {th }}$ edition. New Jersey, NJ: John Wiley \& Sons, Inc.

Gramling, A., Rittenberg, L., \& Johnstone, K. (2012). Auditing. The $8^{\text {th }}$ edition. Canada: South-Western.
Krogstad, J., Ridley, A., \& Ritterberg, L. (1999). Where are we going? Internal Auditor, 56(5), 26-33.

Kukoleča, S. (1995). Osnovi ekonomije. Beograd, Srbija: Savremena administracija.

Lee, T., \& Alan, P. (1984). The Nature, Scope and Qualities of Auditing. In S. Carsberg (Ed.), Current Issues in Auditing, Philip Alan.

Ljubisavljević, S. (2000). Uloga eksternog revizora u okruženju. Kragujevac, Srbija: Ekonomski fakultet.

Meigs, W., Wittington, O., \& Pany, K. (1988). Principles of Auditing. McGraw-Hill, Irwin.

Milojević, D. (2006). Revizija finansijskih izveštaja. Beograd, Srbija: FTB, BBA.

Milosavljević, S., \& Radosavljević, I. (2003). Osnovi metodologije političkih nauka. Beograd, Srbija: Službeni glasnik.

Munro, L., \& Stewart, J. (2011). Exsternal auditors' reliance on internal auditing: further evidence. Managerial Auditing Journal, 26(6), 464-481.

Odluka o osnovnim principima organizacije i rada interne revizije banke i druge finansijske organizacije. (2002). Službeni list SRJ 39.

Pickett, S. (1997). Profesionalna praksa interne revizije. Beograd, Srbija: Savez računovođa i revizora Srbije.

Pickett, S. (2011). The Essential Guide to Internal Auditing. London, UK: John Wiley \& Sons.

Poznanić, V. (2011). Uloga odbora za reviziju u korporativnom upravljanju. Revizor, 13(53), 10-24.

Raschenberger, M. (1929). Internationales Revision und Treuhandwesen. Wien.

Renard, J. (1997). Theorie et pratique de l'audit interne. Paris, Les editions d'organisation.

Rossel, J. (2007). The Internal Auditing Pocket Guide: Preparing, Performing, Reporting and Follow-up. The $2^{\text {nd }}$ Edition. Milwaukee, Wisconsin: American Society for Quality Press, $4,10-25$.

Sarens, G., \& De Beelde, I. (2006). The Relationship between Internal Audit and Senior Management: A Qualitative Analysis of Expectations and Perceptions. International Journal of Auditing, 10(3), 219-241.

Soh, D., \& Martinov-Bennie, N. (2011). The internal audit function: Perceptions of internal audit roles, effectiveness and evaluation. Managerial Auditing Journal, 26(7), 605-622. 
Spahić, N. (2008). Izveštaj interne revizije. Revizor, 10(41), 5-19.

Stuart, I. (2012). Auditing and Assurance Services: An Applied Approach. New York, NY: McGraw-Hill, Irwin.
Zakon o bankama i drugim finansijskim organizacijama (2005), Službeni glasnik RS 107 i izmene ovog zakona, Službeni glasnik RS 91/2010.

$$
\begin{aligned}
& \text { Received on } 11^{\text {th }} \text { February 2013, } \\
& \text { after revision, } \\
& \text { accepted for publication on } 19^{\text {th }} \text { April } 2013
\end{aligned}
$$

Snežana Ljubisavljević is an Associate Professor at the Faculty of Economics, University of Kragujevac. She holds a PhD in business economics - Accounting and Auditing, Faculty of Economics, University of Belgrade. The key areas of her scientific interest and work are the specific areas of the audit of financial statements, internal control and internal audit, and financial institution accounting. 


\title{
ORGANIZOVANJE I ZADACI INTERNE REVIZIJE U DOMAĆIM I STRANIM BANKAMA U REPUBLICI SRBIJI
}

\author{
Snežana Ljubisavljević* \\ Ekonomski fakultet Univerziteta u Kragujevcu
}

\begin{abstract}
U radu je napravljen pokušaj da se na bazi referentne anglosaksonske literature i prakse ustanovi koliki je dostignuti nivo razvoja interne revizije u bankama u Republici Srbiji. Empirijsko istraživanje je obuhvatilo uzorak od 14 banaka u Republici Srbiji, od ukupno 32 banke, sa svrhom da se utvrde načini organizovanja i zadaci interne revizije u njima. Predmet istraživanja u radu je da se utvrdi kako menadžeri i zaposleni na višim funkcijama u banci shvataju ulogu i značaj interne revizije. Cilj rada je da se na bazi odgovora na postavljena pitanja u upitniku daju predlozi za poboljšanje ove važne funkcije banke. Rezultati istraživanja ukazuju na to da veličina banke ne utiče na način organizovanja, odgovornost i zadatke interne revizije banke. Dostignuti nivo razvoja interne revizije u finansijskim organizacijama je na znatno višem nivou $\mathrm{u}$ odnosu na privredne subjekte, ali u mnogim segmentima zaostaje za internom revizijom u razvijenim zemljama sveta.
\end{abstract}

Ključne reči: interna revizija, organizovanje, zadaci, domaće banke, strane banke

JEL Classification: M42, G21, H83

\section{UVOD}

Deregulacija, informacione tehnologije i globalizacija su faktori iz okruženja koji su poslednjih godina posebno uticali na poslovanje banaka. Savremeno svetsko bankartstvo karakteriše izrazita dinamičnost za šta se koristi izraz bankarska revolucija. U uslovima rasta obima poslovanja i diverzifikacije poslova banke, uloga i značaj interne revizije se povećavaju. Banka nastoji da uspostavi adekvatan sistem unutrašnjih kontrola kako bi osigurala dobro uređeno poslovanje

\footnotetext{
* Korespondencija: S. Ljubisavljević, Ekonomski fakultet Univerziteta u Kragujevcu, Đ. Pucara 3, 34000 Kragujevac, Srbija, e-mail: ljubisavljevic@kg.ac.rs
}

i time ostvarila svoje ciljeve. Internom revizijom se obezbeđuje da interne kontrole brzo i tačno izveštavaju o svim izvršenim transakcijama, kao i da se omogući pravilna zaštita sredstava. Pomoću interne revizije se utvrđuje da li banke poštuju zakone, propise, kao i da li menadžment preduzima odgovarajuće mere za rešavanje slabosti u kontroli. Redovan posao organizacione jedinice interne revizije je da omogući nezavisnu procenu, ispitivanja i ocenu aktivnosti banke. $\mathrm{O}$ značaju interne revizije govore i prevare $\mathrm{i}$ gubici od 5 milijardi evra u Societe Generale banci čiji je uzrok bilo nefunkcionisanje sistema internih kontrola. Drugi primer izostanka interne kontrole je slučaj Barings banke koja nije ispoštovala procedure razdvajanja dužnosti. 
Interna revizija ispituje i ocenjuje ukupnost funkcionisanja čitavog poslovnog sistema i daje mišljenje i predloge za poboljšanje njegovog poslovanja. Uloga interne revizije u procesu poslovnog odlučivanja proizlazi iz činjenice da interna revizija utvrđuje pouzdanost, realnost i integritet finansijskih i poslovnih informacija koje dolaze iz različitih organizacionih delova, a na osnovu kojih se donose odgovarajuće poslovne odluke na svim nivoima upravljanja. Ona je organ poslovnog rukovodstva čiji su glavni zadaci: planiranje, organizovanje, dispozicija, koordinacija i nadzor. Interna revizija je značajna jer ima ključnu ulogu u sprečavanju i otkrivanju grešaka i nelegalnih radnji, igra bitnu ulogu u procenjivanju i upravljanju rizicima banke, čime štiti sigurnost njenog poslovanja. Osnovni principi definisani kodeksom profesionalnog ponašanja internih revizora su: nezavisnost i skepticizam, integritet, objektivnost, poverljivost i kompetentnost. Kvalitet i korisnost informacija određuju uspešnost interne revizije, dok eksterna revizija ocenjuje uspešnost interne revizije. Interna revizija štiti poslovni sistem iznutra, štiti vlasnika i menadžment od nesavesnog ponašanja saradnika, a istovremeno vlasnika od menadžmenta banke i u najširem smislu štiti interese javnosti.

Predmet istraživanja u radu su opšti podaci o bankama u Republici Srbiji (RS), organizacioni oblik interne revizije u bankama, njena odgovornost, tj. podređenost i zadaci u posmatranih 14 banaka.

Osnovni cilj ovog rada je da se empirijski potvrde sledeće ključne istraživačke hipoteze:

- Hipoteza 1 (H1): Ne postoji statistički značajna razlika između veličine banke i organizacije interne revizije $\mathrm{u}$ banci.

- Hipoteza 2 (H2): Ne postoji statistički značajna razlika u veličini banke i oceni važnosti zadataka interne revizije u bankama.

- Hipoteza 3 (H3): Nema statistički značajnih razlika između aritmetičkih sredina obeležja (organizacija i zadaci) i odgovora na sva pitanja među velikim, srednjim i malim banaka u populaciji, odnosno, populacija je homogena $u$ pogledu posmatranih karakteristika, obeležja.
Naučni instrumentarijum korišćen u radu je statistička metodologija koja obuhvata statističku deskripciju i statističku analizu. U radu su, takođe, korišćene opšte naučne metode, kao i posebne naučne metode i postupci logičkog zaključivanja. Posebne tehnike za prikupljanje podataka korišćene $u$ radu su: merenje studija slučaja, anketa i intervju.

Rad se sastoji od pet sekcija praćenih zaključkom. U prvoj sekciji, nakon Uvoda, obuhvaćen je istorijski nastanak i razvoj interne revizije kao važne poslovne funkcije svake banke i drugih finansijskih organizacija. Nakon toga, sledi pregled osnovnih zaključaka prethodnih istraživanja, a koja se odnose na predmet istraživanja u ovom radu. Druga sekcija razmatra zadatke $i$ funkciju interne revizije $u$ bankama Republike Srbije. Zatim je prezentovan opis istraživačkih metoda koje su u istraživanju korišćene, kao i podataka koji će se upotrebiti $u$ istraživanju. $U$ poslednjoj sekciji su prezentovani zaključci istraživanja podeljeni u sledeće podsekcije: osnovni podaci o bankama RS, organizacija interne revizije u bankama RS i zadaci interne revizije u bankama RS. Osnovni rezultati sprovedenog istraživanja dati su u Zaključku.

\section{RAZVOJ INTERNE REVIZIJE I PREGLED LITERATURE}

Interna revizija je naknadna kontrola, jer kao interni mehanizam najčešće deluje post festum pošto ispituje završene poslovne promene. U svetskoj računovodstvenoj literaturi je zabeleženo da su oba segmenta internog nadzora (interna kontrola i interna revizija) nastala istovremeno. Ukoliko se govori o prvim segmentima funkcije internog nadzora, mora se uvažiti činjenica da se tekuća i naknadna kontrola (interna revizija) pojavljuju $u$ oblasti rukovanja novčanim sredstvima i to nad licima koja vrše naplatu poreskih dažbina, odnosno, određene novčane transakcije. Postoje pouzdani dokazi da su poreski prihodi u starom Egiptu nadgledani preko dva posebna lica. Prvi oblik kontrole je obavljan za vreme odvijanja procesa rada, a drugi nakon njegovog završetka, $\mathrm{u}$ kraćim ili dužim intervalima. To su bile, u stvari, prethodna i naknadna kontrola - odnosno, interna revizija. Atribut "interna" potiče otuda što je lice koje je 
sprovodilo naknadnu kontrolu bilo u radnom odnosu kod određene poreske ili budžetske institucije. Jasno je da tada nije postojao termin "revizija", koji je nastao znatno kasnije sa ciljem adekvatnog razdvajanja tekuće i naknadne kontrole. Pored toga, istorijski izvori razvoja interne revizije ukazuju na to da je u antičkoj Grčkoj postojala naknadna kontrola finansijskih transakcija u državnim i drugim rizičnim institucijama. $U$ tom smislu, tzv. "logisti" u tadašnjoj Atini su preispitivali poslovanje računopolagača $u$ vezi sa rukovanjem finansijskim sredstvima. To preispitivanje vršeno je $\mathrm{u}$ određenim intervalima tokom godine i obavezno na kraju godine. S obzirom na to da je prethodnu, tekuću kontrolu obavljao naredbodavac $\mathrm{u}$ toku godine, očigledno je da su pomenuti „logisti“ bili prvi revizorski činovnici. U poznatoj rimskoj republici razvio se složen sistem interne revizije kao oblika kontrole nad internim kontrolama (Raschenberger, 1929). Postoje izvesni dokazi o nastanku interne revizije u Italiji. Tako je pronađen zapisnik o reviziji iz 831. godine, u Pizi. Pisani izvori ukazuju na to da je interna revizija funkcionisala 1285 . godine i u nekim engleskim gradovima. Tokom 1299. godine imenovani su interni revizori grada Londona, koji su ispitivali račune u kraljevskom vlasništvu. Kasnije je interna revizija sve više organizovana ne samo od strane državnih institucija, već i od strane krupnijih privrednih preduzetnika i banaka (Stuart, 2012).

Razvoj interne revizije $\mathrm{u}$ ranom razvojnom periodu tekao je prilično usporeno. Za njom se osećala sve veća potreba, jer preduzetnici nisu imali mogućnosti i sposobnosti da neposredno sprovode naknadnu kontrolu. Glavna preokupacija interne revizije $u$ tom periodu bila je da ispituje tačnost i urednost knjigovodstva, kao i eventualne zloupotrebe, pronevere i druge oblike prisvajanja imovine vlasnika. Pored toga, usporenost razvoja interne revizije ranog razvojnog perioda karakteriše nerazvijeno bankarstvo, preduzetništvo, mala preduzeća i sl. Razvoj banaka i porast veličine preduzeća uslovili su potrebu za jačanjem interne revizije.

U savremenim uslovima poslovanja, rukovodstvo poslovnog sistema je odgovorno za uspešno funkcionisanje internog nadzora. Poslovno rukovodstvo je dužno da uspostavi interne kontrole koje obavljaju svi zaposleni kao sastavni deo njihovih redovnih radnih obaveza i da vrši nadzor nad njihovim funkcionisanjem. Međutim, rukovodstvo je preokupirano tekućim poslovnim aktivnostima, tako da nije u stanju da sprovodi neposredni nadzor nad internim kontrolama. Da bi se prevazišao ovaj problem, rukovodstvu vlasnik kapitala ili drugi organ odobrava formiranje posebne organizacione jedinice interne revizije.

Interna revizija se razvijala uporedo sa povećanjem složenosti upravljanja poslovnim sistemom. Taj razvoj se, $\mathrm{u}$ osnovi, deli na dva perioda. Period do nastanka i završetka velike ekonomske krize (1929-1933.) i period prosperiteta posle završetka Krize. Razvoj savremene interne revizije otpočeo je polovinom XIX veka, formiranjem prvih revizorskih organizacionih jedinica $\mathrm{u}$ velikim kapitalističkim preduzećima i bankama u organizacionom obliku sektora, službi ili odeljenja interne revizije (Milojević, 2006).

U SAD su počele da se formiraju prve organizacione jedinice za internu reviziju 1864. godine. Međutim, poseban razvojni trend dobila je interna revizija u SAD 1942. godine, kada je osnovan Institut internih revizora. Novoformiran Institut imao je snažan uticaj na razvoj interne revizije u svetu. Tako je, nakon 25 godina rada, obuhvatio članove sa svih kontinenata. U toku 1947. godine, $u$ SAD-u učinjen je još jedan značajan potez $u$ pravcu jačanja i daljeg razvoja interne revizije. Institut internih revizora doneo je i objavio Izjavu o obavezama i odgovornostima internih revizora, čime je potpunije definisan njihov položaj. Ova Izjava predstavlja prvi korak ka donošenju standarda profesionalne prakse interne revizije (Poznanić, 2011).

U Nemačkoj je 1875. godine formirano prvo odeljenje interne revizije, što istovremeno predstavlja i prvo organizovanje interne revizije u Evropi. Odluku o formiranju ove organizacione jedinice doneo je Odbor prokurista firme Krupp. Delokrug rada ovog odeljenja za internu reviziju nije se ograničavao samo na nadzor nad knjigovodstvom, već je obuhvatao i neke druge vitalne aktivnosti, kao što su ostvarivanje planova, poštovanje propisa, ugovora, uputstava za rad i sl. Po ugledu na SAD, u Nemačkoj je 1958. godine formiran Institut interne revizije, čiji su zadaci bili isti kao i kod Instituta internih revizora SAD (Picket, 2011). 
Uvođenje interne revizije $\mathrm{u}$ Francuskoj usledilo je znatno kasnije u odnosu na SAD i Nemačku. Usporavanju razvoja interne i eksterne revizije doprineo je specifičan sistem nadzora od strane tzv. komesara vlade i državnih kontrolora. Šezdesetih godina prošlog veka u Francuskoj je intenziviran razvoj interne i eksterne revizije $u$ firmama i bankama u koje su inostrani subjekti uložili kapital. Od tada počinje da raste broj internih revizora, što je direktno uticalo na to da se 1965. godine osnuje Francusko udruženje internih revizora, koje je 1973. godine preraslo u Francuski institut internih revizora.

Iz razvijenih zemalja praksa interne revizije se širi u sve zemlje sveta.

Što se teorijskog okvira interne revizije tiče, navešćemo neke od najznačajnijih definicija interne revizije koje sadrže svrhu, cilj i zadatke ove funkcije. Istaknuti svetski teoretičar revizije $\mathrm{T}$. Li je devedesetih godina 20. veka reviziju definisao na sledeći način: "U najširem smislu reči revizija je sredstvo pomoću koga se jedno lice uverava od strane drugog lica u kvalitet, stanje ili status nekog predmetnog pitanja koje je ovo drugo lice ispitivalo; potreba za revizijom nastaje jer je pomenuto lice u nedoumici ili sumnja u kvalitet, stanje ili status predmetnog pitanja, a nije lično $u$ stanju da otkloni tu sumnju ili nedoumicu" (Lee \& Alan, 1984, 213). Zadatak interne revizije je da istražuje, ispituje i ocenjuje sistem internih kontrola i njegovu efikasnost $\mathrm{u}$ delovanju svakog pojedinog poslovnog sistema, da izveštava o nalazima i da predlaže rešenja menadžmentu (Meigs, Whittington \& Pany, 1988). Interna revizija ispituje organizaciju i funkcionisanje računovodstvenog sistema i pripadajućih internih kontrola, verodostojnost finansijskih i operativnih informacija, ocenjuje ekonomičnost, efikasnost i efektivnost poslovnih operacija i kontrola, kao i primenu politika, planova i procedura.

Revizija i revizorski posao nisu karakteristični samo za ekonomsko privređivanje, nego je njihova primena mnogo šira, što $S$. Kukoleča ističe u sledećoj definiciji: "Svaka sistemska i detaljno sprovedena naknadna kontrola poslovanja organizacije ili revizija finansijskog poslovanja obuhvata detaljno ispitivanje čitavog poslovanja ili ispitivanje jednog užeg sektora; vrši se kada je potrebno precizno rasvetliti pravo stanje, kada se sumnja na postojanje finansijskih zloupotreba, ili kada je to potrebno organima upravljanja iz nekih posebnih razloga" (Kukoleča, 1995, 131).

Američki institut ovlašćenih javnih računovođa (American Institute of Chartered Public Accountants - AICPA) definisao je reviziju kao sistemski proces objektivnog prikupljanja i vrednovanja dokaza o tvrdnjama $u$ vezi sa ekonomskim akcijama i događajima do nivoa pouzdanosti korespondencije tih tvrdnji i ustanovljenih kriterijuma, kao i saopštavanje rezultata zainteresovanim korisnicima.

G. Vinten ističe da je interna revizija kontinuirano i opsežno istraživanje naizgled dobrih organizacija sa ciljem sticanja uvida u realno stanje ili položaj organizacije i njenog okruženja, radi postizanja bolje kontrole nad budućim poslovanjem (Picket, 1997). Za razliku od svih prethodnih definicija interne revizije, ova definicija naglašava potrebu usmerenosti interne revizije poboljšanju budućeg poslovanja, a ne samo pregledanju prošlih događaja.

Interna revizija je delotvoran instrument menadžerske kontrole. Iako se često ograničava na reviziju računa, ona se $u$ svom području rada odnosi na ocenu poslovanja u celini (Munro \& Stewart, 2011). Tako interni revizori, $u$ pokušaju provere verodostojnosti dokumentacije, takođe ocenjuju politiku, procedure, kvalitet odlučivanja i upravljanja, delotvornost metoda i postupaka i druge specifične probleme poslovanja (Krogstad, Ridley \& Ritterbeg, 1999).

Interna revizija banke se definiše kao "nezavisna funkcija upravljanja koja uključuje stalnu i kritičku ocenu banke kako bi dala sugestije za njeno poboljšanje, stvorila vrednost i ojačala ukupan mehanizam upravljanja uključujući upravljanje rizikom subjekta i sistemom interne kontrole" (Rossel, 2007, 18). Zadatak interne revizije je da "istražuje, ispituje i ocenjuje sistem internih kontrola i njihovu efikasnost $u$ delovanju svakog posebnog poslovnog dela, da izveštava o nalazima i da predlaže rešenja menadžmentu" (Allen, Sneathen \& Tim, 2007, 156). Sektor interne revizije pomaže organizaciji u izvršavanju postavljenih ciljeva i donesenih pravila na sistematičan i disciplinovan način, preko evaluacije 
i poboljšanja efektivnosti procene rizika, kontrole manadžmenta i sistema upravljanja procesima u banci (Renard, 1997). Prema R. Moeller-u, interna revizija je nezavisna procena poslovnih funkcija ustanovljena $\mathrm{u}$ organizaciji sa ciljem ispitivanja $\mathrm{i}$ ocene njenih aktivnosti, pa predstavlja uslugu koja se pruža toj organizaciji (Boynton \& Johnson, 2006).

U profesionalnoj praksi, interna revizija se definiše kao "aktivnost nezavisnog, objektivnog uveravanja i konsultantska aktivnost osmišljena sa ciljem kreiranja dodate vrednosti i unapređenja poslovanja banke" (Spahić, 2008, 11).

Dž. Moris, predsednik Instituta za internu reviziju Ujedinjenog Kraljevstva, dao je sledeću izjavu: "Nesumnjivo je da stručnjaci za internu reviziju u Velikoj Britaniji igraju veliku ulogu u pomoći rukovodiocima pri održavanju unutrašnje kontrole." Zatim zaključuje da interna revizija postaje funkcija koja se sastoji od različitih poslovnih delatnosti, koja se sve više širi, kako u procesu upravljanja, tako i u istraživanju i u razvoju banke. G. Vinten ističe "da je interna revizija kontinuirano i opsežno istraživanje naizgled dobrih organizacija sa ciljem uvida u realno stanje ili položaj banke i njenog okruženja radi postizanja bolje kontrole nad budućim poslovanjem" (Gramling, Rittenberg \& Johnstone, 2012, 972).

Iz ovih definicija revizije proizlazi da je interna revizija konsultantska aktivnost koja pored redovnih zadataka omogućava i kreiranje dodate vrednosti banke, odnosno, dodavanje vrednosti akcijama vlasnika. Takođe, u moderno organizovanoj banci interni revizori mogu imati ključnu ulogu u otkrivanju i sprečavanju nezakonitih radnji. Prevare i neovlašćene aktivnosti obuhvataju područje nezakonitih radnji, koje karakteriše namerna prevara, odnosno, obmana. One mogu biti izvršene $u$ korist ili na štetu banke, od strane lica zaposlenih $\mathrm{u}$ banci ili od strane eksternih lica. Stoga je važan zadatak interne revizije ocena usklađenosti poslovanja sa zakonom, poslovnom praksom i postupcima menadžmenta. U tu svrhu interni revizori ocenjuju uspešnost računovodstvenog sistema i sistema unutrašnjih kontrola u banci (Soh \& Martinov-Bennie, 2011). Na kraju, uloga interne revizije se sastoji $u$ uticaju na blagovremeno sastavljanje finansijskih izveštaja i doprinosi korporativnom upravljanju bankom uopšte (Ljubisavljević, 2000).

\section{FUNKCIJE INTERNE REVIZIJE U BANKAMA U RS}

Prema Zakonu o bankama i drugim finansijskim organizacijama (Sl. glasnik RS 107/2005) i izmenama ovog Zakona (Sl. glasnik RS 91/2010) definisane su sledeće oblasti interne kontrole i revizije:

- unutrašnja kontrola,

- funkcija kontrole usklađenosti poslovanja banke,

- funkcija unutrašnje revizije,

- ovlašćenja unutrašnje revizije i

- godišnji izveštaj o adekvatnosti upravljanja rizicima i unutrašnjoj kontroli.

Prema navedenom Zakonu, kontrolu pravilnosti rada banke u RS i efikasnosti funkcionisanja sistema unutrašnjih kontrola vrše unutrašnja (interna) revizija i odbor za praćenje poslovanja banaka. Osnovni zadatak organizacione jedinice unutrašnje revizije je da upravnom odboru banke pruža nezavisno i objektivno mišljenje o pitanjima koja su predmet revizije. Takođe, interna revizija obavlja savetodavnu aktivnost usmerenu na unapređenje postojećeg sistema internih kontrola (Sarens \& De Beelde, 2006), a upravnom odboru banke pruža pomoć u ostvarivanju njegovih ciljeva. Sve navedeno, unutrašnja revizija obavlja primenjujući sistematičan, disciplinovan i dokumentovan pristup vrednovanju i unapređenju postojećeg načina upravljanja rizicima, kontrole i rukovođenja procesima. Shodno navedenim nadležnostima, Zakon definiše sledeće funkcije unutrašnje revizije:

- ocena adekvatnosti i pouzdanosti sistema unutrašnjih kontrola banke i funkcije kontrole usklađenosti poslovanja banke;

- obezbeđenje da se rizici na odgovarajući način identifikuju i kontrolišu;

- utvrđivanje slabosti u poslovanju banke i njenih zaposlenih, kao i slučajeva neizvršenja obaveza i prekoračenja ovlašćenja i pripremanje predloga za otklanjanje tih slabosti i preporuka za njihovo sprečavanje;

- održavanje sastanaka sa upravnim odborom banke, kao i odborom za praćenje poslovanja banke; i

- redovno pripremanje izveštaja o aktivnostima unutrašnje revizije i njihovo dostavljanje upravnom odboru i odboru za praćenje poslovanja banke. 
Za navedene poslove, unutrašnja revizija mora da se organizuje kao nezavisna organizaciona jedinica $u$ banci. Banka je dužna da postupke sistema internih kontrola uredi i sprovodi na način da omogućavaju kontinuirano praćenje i merenje rizika koji mogu negativno uticati na ostvarivanje utvrđenih poslovnih ciljeva banke, kao što su: kreditni rizik, rizik zemlje dužnika, devizni rizik, rizik tržišta, kamatni rizik, rizik likvidnosti, operativni i drugi rizici. Banka je dužna da sistem internih kontrola razvija na način koji omogućava blagovremenu procenu postojećih i novih rizika, uključujući i rizike koji prethodno nisu kontrolisani, kao i rizike izvan kontrole banke (spoljni rizici), i kontrolu tih rizika koja će negativne uticaje na poslovanje i bonitet banke svesti na najmanju moguću meru.

$\mathrm{U}$ banci postoji organizaciona jedinica $u$ čijem delokrugu je kontrola usklađenosti poslovanja banke. Rukovodilac ove jedinice je odgovoran za identifikaciju i praćenje rizika usklađenosti poslovanja banke i za upravljanje tim rizikom, koji posebno obuhvata rizik od sankcija regulatornog tela i finansijskih gubitaka, kao i reputacioni rizik. Rizik usklađenosti poslovanja banke nastaje kao posledica propuštanja usklađivanja poslovanja sa Zakonom i drugim propisom, standardima poslovanja, procedurama o sprečavanju pranja novca, kao i sa drugim aktima kojima se uređuje poslovanje banke. Zaposleni u banci su dužni da ovoj organizacionoj jedinici omoguće uvid u dokumentaciju koju poseduju i da joj pruže potrebne informacije. Organizaciona jedinica u čijem delokrugu je kontrola usklađenosti poslovanja banke dužna je da najmanje jednom godišnje identifikuje i proceni glavne rizike te usklađenosti i predloži planove upravljanja tim rizicima, o čemu sastavlja izveštaj. Ova organizaciona jedinica je dužna da sastavi program praćenja usklađenosti poslovanja banke, koji posebno sadrži metodologiju rada te organizacione jedinice, planirane aktivnosti, načine i rokove izrade izveštaja, način provere te usklađenosti kao i plan obuke zaposlenih.

Što se interne revizije tiče, rukovodilac interne revizije izrađuje program unutrašnje revizije i utvrđuje metodologiju njenog rada, a posebno uputstvo za rad unutrašnje revizije, način i rokove izrade i dostavljanja nadležnim organima banke izveštaja o unutrašnjoj reviziji, način praćenja preporučenih aktivnosti za otklanjanje nepravilnosti i nedostataka u poslovanju banke, kao i način i odgovornost za izradu, korišćenje i čuvanje dokumentacije o obavljenim aktivnostima unutrašnje revizije prema godišnjem planu. Rukovodilac organizacione jedinice interne revizije odgovoran je za efikasno, kontinuirano, redovno i kvalitetno vršenje funkcije interne revizije i efikasno sprovođenje programa i operativnih godišnjih planova te revizije. Što se ovlašćenja unutrašnje revizije tiče, zaposleni u ovoj organizacionoj jedinici imaju pravo uvida $u$ sva dokumenta banke i njenih podređenih društava kao i članova iste bankarske grupe, da bi bez ograničenja vršili nadzor nad poslovanjem banke. Unutrašnji revizori učestvuju na sednicama upravnog odbora banke. Godišnji izveštaj o adekvatnosti upravljanja rizicima i unutrašnjoj kontroli, banka dostavlja zajedno sa godišnjim finansijskim izveštajima.

Zakon definiše funkcije i zadatke odbora za praćenje poslovanja banaka, unutrašnje revizije, funkcije unutrašnje kontrole, njihov međusobni odnos, kao i odnos sa drugim organima: upravnim odborom, skupštinom banke i izvršnim odborom. Odbor za praćenje poslovanja banke vrši kontrolu pravilnosti rada banke i prati funkcionisanje sistema interne kontrole. Ovu funkciju vrši i interna revizija banke, dok rukovodilac interne revizije izveštaje o svom radu podnosi ovom odboru. Dok interna kontrola prožima sve organizacione jedinice i ugrađena je $u$ organizacionu strukuru banke, interna revizija ocenjuje efikasnost sistema internih kontrola i organizovana je kao posebna organizaciona jedinica banke. Upravni odbor banke imenuje i razrešava rukovodioca organizacione jedinice $u$ čijem delokrugu je kontrola usklađenosti poslovanja banke. Takođe, upravni odbor bira i razrešava rukovodioca organizacione jedinice u čijem je delokrugu interna revizija. Organizaciona jedinica za internu reviziju izveštaje o svom radu podnosi upravnom odboru banke. Na kraju, ovaj odbor odobrava godišnji izveštaj o adekvatnosti upravljanja rizicima i internoj kontroli banke. Skupština banke se obaveštava od strane rukovodioca interne revizije o sazivanju sednice odbora za praćenje poslovanja banke i o neodržavanju zakazane sednice. Izvršni odbor usvaja izveštaj organizacione jedinice u čijem delokrugu je kontrola usklađenosti poslovanja banke. Izvršni odbor i odbor za praćenje poslovanja banke 
se obaveštavaju od strane rukovodioca organizacione jedinice $u$ čijem delokrugu je kontrola usklađenosti poslovanja banke o utvrđenim propustima koji se odnose na usklađenost poslovanja. Clanovi izvršnog odbora banke su odgovorni za vršenje interne kontrole u njoj. Narodnoj banci Srbije, banka je dužna da dostavi godišnje izveštaj o adekvatnosti upravljanja rizicima i unutrašnjoj kontroli banke. Sadržinu ovog godišnjeg izveštaja i rokove njegovog dostavljanja bliže propisuje Narodna banka Srbije, s tim da ovaj izveštaj mora da sadrži sledeće izjave:

- da li su upravni i izvršni odbor banke identifikovali značajne rizike;

- da li su politike unutrašnje kontrole i upravljanja rizicima u banci adekvatne $\mathrm{i}$ da li se efikasno primenjuju;

- da li su Narodnoj banci Srbije dostavljeni tačni prikazi politika upravljanja rizicima i sistema unutrašnjih kontrola;

- da je utvrđen plan aktivnosti za otklanjanje nedostataka i da se primenjuje ili da će biti utvrđen i dostavljen na usvajanje upravnom odboru banke.

Pored Zakona o bankama i drugim finansijskim organizacijama, guverner Narodne banke Jugoslavije doneo je Odluku o osnovnim principima organizacije i rada interne revizije banke i druge finansijske organizacije (Sl. list SRJ 39/2002) kojom se određuju osnovni ciljevi interne revizije, tako da se na taj način obezbeđuje zaštita boniteta banke i realno iskazivanje njenog finansijskog rezultata. Ovom odlukom se, takođe, definiše:

- nezavisnost internog revizora od direktora banke i lica sa posebnim ovlašćenjima i odgovornostima u banci;

- da interni revizor ne sme da obavlja rukovodeće poslove u banci;

- samostalnost internog revizora kod odluke o izboru metodologije rada i načina njene primene;

- da je banka dužna da funkciju interne revizije obavlja u skladu sa međunarodno priznatim standardima interne revizije i revizije poslovanja banaka;

- nadležnosti upravnog odbora u aktima banke (usvajanje programa i operativnog godišnjeg plana revizije i uslova za njihovo sprovođenje, imenovanje internog revizora $\mathrm{i}$ utvrđivanje visine njegovih primanja i sl.);

- obavezu internog revizora da izveštaje dostavlja nadzornom odboru, direktoru banke i licima sa posebnim ovlašćenjima i odgovornostima $u$ banci nadležnim za otklanjanje utvrđenih nepravilnosti i nedostataka;

- učestalost revizije koju treba povećati u oblastima poslovanja banke sa višim stepenom rizika;

- da direktor i lica sa posebnim ovlašćenjima i odgovornostima u banci moraju biti odgovorni za prihvatanje ili odbijanje preporuka internog revizora, a i za to da li su nepravilnosti i nedostaci u poslovanju banke efikasno otklonjeni.

Iz prethodno navedenih propisa ostaje nejasno da li interni revizor svoje mišljenje izraženo u revizorskom izveštaju dostavlja upravnom, nadzornom odboru ili menadžmentu banke. Empirijsko istraživanje je upravo pokazalo da je interna revizija u bankama u RS podređena različitim organima banke.

\section{METODOLOGIJA ISTRAŽIVANJA}

Istraživanje obuhvata 14 banaka u Republici Srbiji sa osnovnim ciljem da se utvrde načini organizovanja i zadaci interne revizije u njima. Istraživanje je obavljeno u prvom kvartalu 2011. godine pomoću studije preseka - ankete. Empirijsko istraživanje podrazumeva sve aktivnosti od početka prikupljanja podataka putem upitnika do primene rezultata istraživanja $u$ društvenoj praksi. Istraživanje su činili (Milosavljević \& Radosavljević, 2003):

- predistraživanje, sa rekonstrukcijom projekta, kako o projektu istraživanja i saradnicima, tako i o samoj pojavi i predmetu istraživanja;

- prikupljanje, sređivanje, grupisanje i obrada podataka za potrebe empirijskog istraživanja (metode statističke deskripcije);

- analiza prikupljenih podataka (statistička analiza);

- zaključivanje i prikaz rezultata istraživanja na osnovu kvantitativno izvedenih zaključaka i

- preporuke o korišćenju rezultata istraživanja u praksi. 
Posebne tehnike za prikupljanje podataka ili metode korišćane $u$ radu su: naučno posmatranje, metode istraživanja uzroka, analiza sadržaja, anketa i intervju. Varijable $\mathrm{tj}$. promenlijive $\mathrm{u}$ anketi su velike, srednje $\mathrm{i}$ male banke, zadaci interne revizije u bankama koji su svrstani $u$ šest grupa, organizovanje interne revizije banaka i ocene odgovora 14 anketiranih banaka koje se odnose na zadatke interne revizije i način organizovanja interne revizije $\mathrm{u}$ ovim bankama.

Što se podskupova i uzorka tiče, istraživanje je sprovedeno na 14 elementarnih jedinica od čega su 5 velike banke, 5 srednje banke i 4 male banke. Anketom su obuhvaćene sve velike i srednje banke što znači da su to dva podskupa, stratuma. Za male banke se izvodi zaključak da je istraživanje sprovedeno na prostom slučajnom uzorku od 4 elementarne jedinice. Anketu su popunjavali rukovodioci interne revizije i menadžeri na drugim nivoima poslovanja u banci. Što se opisa mernog instrumenta tiče, upitnik se sastoji iz dva glavna dela. Na početku ankete, banke navode osnovne podatke i ovi podaci su grupisani u 6 pitanja. Drugi deo upitnika obuhvata 7 pitanja, koja se odnose na način organizovanja interne revizije $u$ bankama i na zadatke interne revizije banaka. Skale su, u zavisnosti od pitanja i ponuđenih odgovora, različite i kreću se od:
1-3 (veličina banaka, organizacija banaka i članstvo u eksternom ili internom telu banke) i 1-5 (podređenost internog revizora i ocena zadataka interne revizije u bankama). Svi prikupljeni podaci o anketiranim bankama su sačuvani u bazi podataka Microsoft Exel 2007. Analiza statističkih podataka rađena je pomoću metoda statističke deskripcije: podaci su prikupljeni, grupisani i prikazani pomoću histograma kruga.

\section{REZULTATI ISTRAŽIVANJA}

\section{Osnovni podaci o bankama}

Ovi podaci su grupisani u sledećih 6 pitanja: naziv, sedište i zemlja porekla banke; domaća ili strana banka; organizacioni oblik banke (centrala, filijala, predstavništvo strane banke); filijala/predstavništvo, okrug; bankarska grupa ili holding; ukupan broj zaposlenih, ukupan prihod i ukupna imovina u 2011. godini.

Banke koje nisu htele da popune upitnike to su objasnile nedostatkom vremena i tajnošću podataka. Od ukupnog broja banaka, 64\% su banke sa stranim kapitalom, dok je 36\% domaćih banaka, što se vidi iz Tabele 1. Za rangiranje banaka na velike, srednje i male

Tabela 1 Rangiranje banaka iz uzorka

\begin{tabular}{clccr}
\hline Red. broj & Banka & Br. zaposl. & Ukupna imovina & Ukupan prihod \\
\hline 1 & Banka Intesa & 3116 & 359.123 .000 .000 & 58.296 .611 .000 \\
2 & Raiffeisen Banka & 2000 & 178.833 .012 .000 & 36.397 .803 .000 \\
3 & Komercijalna Banka & 3105 & 255.868 .309 .000 & 28.683 .475 .000 \\
4 & Societe Generale Banka & 1300 & 163.433 .939 .000 & 18.723 .903 .000 \\
5 & Aik Banka & 478 & 141.583 .427 .000 & 14.890 .254 .000 \\
6 & ProCredit Banka & 2000 & 69.671 .964 .000 & 12.965 .608 .000 \\
7 & Vojvođanska Banka & 2589 & 87.112 .877 .000 & 10.187 .080 .000 \\
8 & Univerzal Banka & 500 & 35.055 .548 .000 & 5.453 .077 .000 \\
9 & KBC Banka & 611 & 29.068 .855 .000 & 4.275 .489 .000 \\
10 & Čačanska Banka & 387 & 28.673 .216 .000 & 4.070 .348 .000 \\
11 & Findomestic Banka & 460 & 18.586 .544 .000 & 3.471 .556 .000 \\
12 & Credit Agricole Banka & 959 & 34.156 .354 .000 & 1.700 .173 .000 \\
13 & Credy Banka & 390 & 10.935 .176 .000 & 1.180 .818 .000 \\
14 & Alpha Banka & 1538 & 98.370 .114 .000 & 1.068 .279 .000 \\
\hline
\end{tabular}

Izvor: Autor, prema podacima iz Ankete 
uzet je kriterijum ostvarenih ukupnih prihoda u 2011. godini.

\section{Organizovanje interne revizije $\mathbf{u}$ bankama}

Na osnovu sprovedenog istraživanja putem direktnog popunjavanja anketnog upitnika o organizovanju interne revizije u bankama, došlo se do sledećih rezultata.

Kod svih 14 banaka (100\% ispitanih), interna revizija je organizovana kao samostalna organizaciona jedinica i interni revizor je nezavisno lice, što je utvrđeno Zakonom o bankama. Interna revizija može biti organizovana kao sektor, odeljenje ili služba, što zavisi, pre svega, od veličine banke. Interna revizija je organizovana kao sektor u sledećim bankama: Univerzal banci, Intesa banci, Komercijalnoj banci, Findomestic banci, Alpha banci i Vojvođanskoj banci. Interna revizija je organizovana kao odeljenje u sledećim bankama: Credit Agricole banci, Societe Generale banci, Raiffeisen banci, KBC banci i Credy banci. Interna revizija je organizovana kao služba u: AIK banci, ProCredit banci i Čačanskoj banci.

Interna revizija je hijerarhijski podređena upravnom odboru u sledećim bankama: Credit Agricole banci, Čačanskoj banci, Findomestic banci i ProCredit banci. Interna revizija je podređena menadžmentu banke u: Intesi banci, Societe Generale banci, Raiffeisen banci i Vojvođanskoj banci. Izvršnom odboru interna revizija je podređena u: KBC banci, AIK banci i Credy banci. Odboru (komitetu) za reviziju je odgovorna interna revizija u sledećim bankama: Alpha banci i Komercijalnoj banci. Samo je Univerzal banka odgovorila da su interni revizori podređeni skupštini akcionara.

Iz prethodno navedenog, a ilustrovanog na Grafikonu 1, možemo zaključiti da je interna revizija organizovana kao:

- sektor u 6 banaka, što predstavlja 42,86\% ispitanih;

- služba u 3 banke, što predstavlja 21,43\% ispitanih; i

- odeljenje u 5 banaka, što predstavlja $35,71 \%$ ispitanih banaka.

Što se organizovanja interne revizije u bankama RS tiče, možemo zaključiti da je u najvećem broju banaka

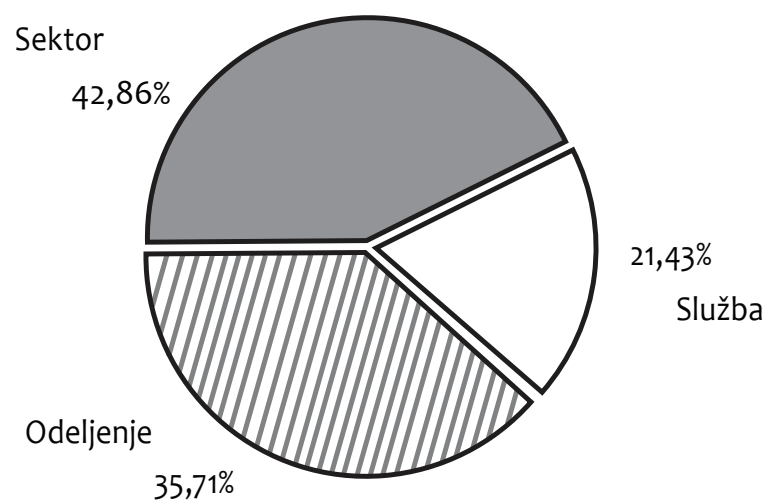

Grafikon 1 Organizovanje interne revizije u bankama

Izvor: Autor, prema podacima iz Ankete

ona organizovana kao sektor, zatim kao odeljenje dok je najmanji broj banaka organizovao internu reviziju $u$ organizacionom obliku službe.

Interna revizija je podređena, tj. odgovorna, što se vidi na Grafikonu 2:

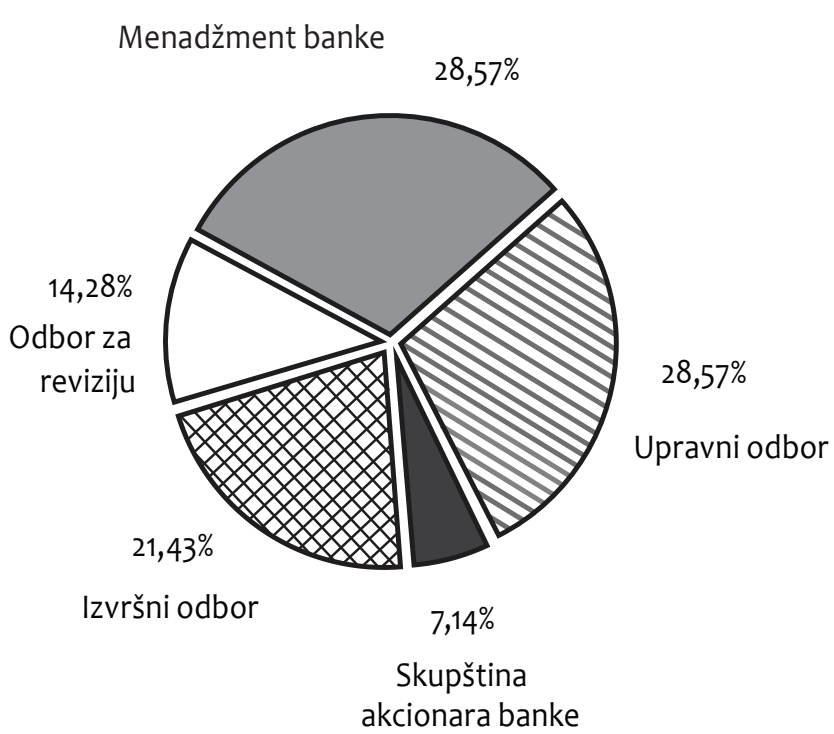

Grafikon 2 Podređenost interne revizije

Izvor: Autor, prema podacima iz Ankete 
- menadžmentu banke u 4 banke, što predstavlja 28,57\% ispitanih;

- upravnom odboru u 4 banke, što predstavlja $28,57 \%$ ispitanih;

- izvršnom odboru u 3 banke, što predstavlja $21,43 \%$ ispitanih;

- odboru za reviziju u 2 banke, što predstavlja $14,28 \%$ ispitanih; i

- skupštini akcionara u 1 banci, što predstavlja 7,14\% ispitanih banaka.

Interna revizija u bankama RS je najčešće podređena upravnom odboru i menadžmentu banke, dok je manji broj banaka internu reviziju podredio izvršnom odboru, odboru za reviziju i skupštini akcionara banke.

\section{Zadaci interne revizije $\mathbf{u}$ bankama}

Na osnovu sprovedenog istraživanja putem direktnog popunjavanja anketnog upitnika o zadacima interne revizije u bankama, došlo se do sledećih rezultata:

- deset banaka, tj. 71,43\% ispitanih, u potpunosti se složilo da je ocena usklađenosti poslovanja sa Zakonom, politikama i poslovnom praksom banke zadatak interne revizije i dali ocenu 5, što ukazuje na zaključak da je to primarni zadatak interne revizije u bankama u RS;

- četiri banke, tj. 28,57\% ispitanih dalo je ocenu 4 , što znači da se slažu sa tim, što je predstavljeno na Grafikonu 3.

Iz Grafikona 3 jasno se uočava da je primarni zadatak interne revizije u bankama u RS ocena usklađenosti sa Zakonom, politikama i poslovnom praksom banke.

Na Grafikonu 4 prikazano je kako su menadžeri banaka rangirali zadatak unutrašnje revizije koji se odnosi na ocenu uspešnosti računovodstvenog sistema i sistema internih kontrola.

Pet banaka, tj. 35,71\% ispitanih, se u potpunosti složilo da je ocena uspešnosti računovodstvenog sistema i sistema internih kontrola zadatak interne revizije i dali ocenu 5; pet banaka, tj. 35,71\% ispitanih, dalo je ocenu 4, što znači da se slažu sa tim; dve banke, tj. 14,28\%

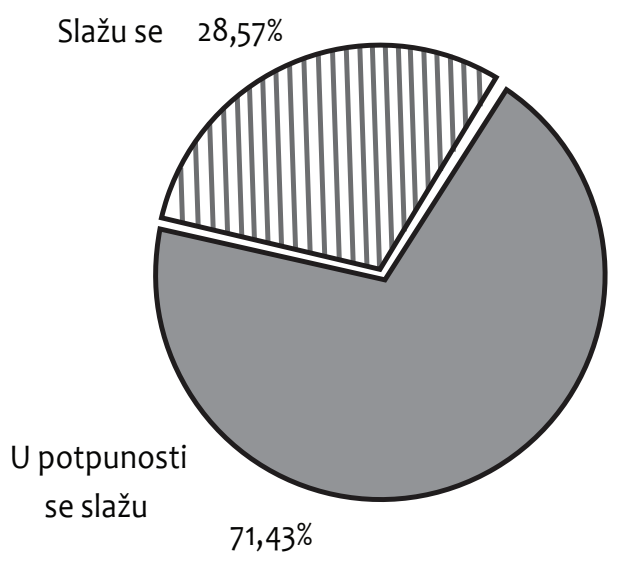

Grafikon 3 Ocena usklađenosti poslovanja sa zakonom, politikama i poslovnom praksom banke

Izvor: Autor, prema podacima iz Ankete

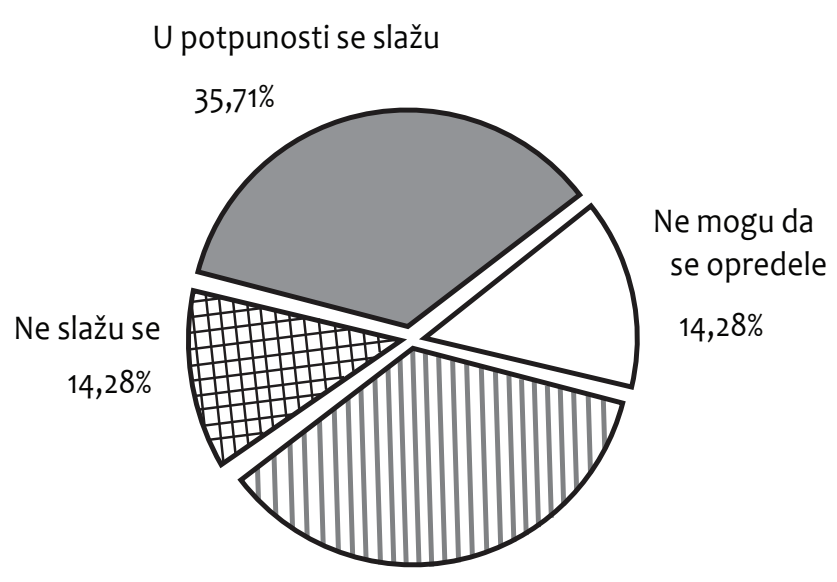

$35,71 \%$

Slažu se

Grafikon 4 Ocena uspešnosti računovodstvenog sistema i sistema internih kontrola

Izvor: Autor, prema podacima iz Ankete

ispitanih, dalo je ocenu 3, što znači da ne mogu da se opredele da li je to zadatak interne revizije; dve banke, tj. $14,28 \%$ ispitanih, dalo je ocenu 2 , što znači da se ne slažu sa tim da je to zadatak interne revizije. 
Većina banaka u RS uočava kao primarni zadatak unutrašnje revizije ocenu uspešnosti računovodstvenog sistema i sistema unutrašnjih kontrola. Više od $70 \%$ ispitanih banaka se slaže, ili se u potpunosti slaže, da je ocena uspešnosti računovodstvenog sistema i sistema unutrašnih kontrola primaran zadatak interne revizije.

Grafikon 5 prikazuje da je otkrivanje i sprečavanje grešaka i nelegalnih radnji važan zadatak interne revizije u bankama RS.

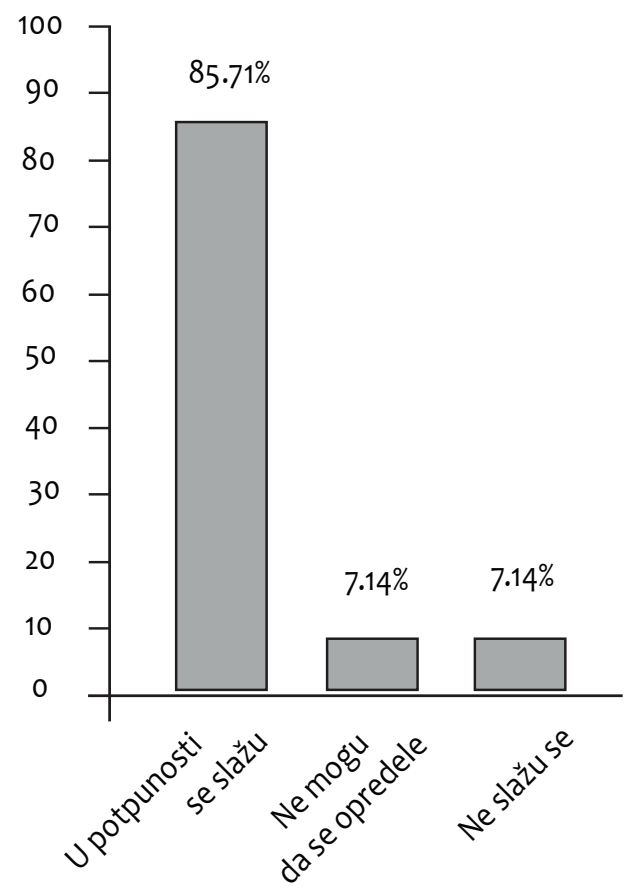

Grafikon 5 Otkrivanje i sprečavanje grešaka i
nelegalnih radnji

Izvor: Autor, prema podacima iz Ankete

Dvanaest banaka, tj. 85,71\% ispitanih, u potpunosti se složilo da je otkrivanje i sprečavanje grešaka i nelegalnih radnji zadatak interne revizije i dali su ocenu 5; jedna banka, tj. 7,14\% ispitanih, nije mogla da se opredeli da li je to zadatak interne revizije i dala ocenu 3; jedna banka, tj. 7,14\% ispitanih, se nije složila da je to zadatak interne revizije i dala je ocenu 2.
Grafikon 6 ilustruje kako su menadžeri banaka u RS odgovorili na pitanje iz upitnika koje se odnosilo na to da li oni smatraju da je blagovremeno sastavljanje kvalitetnih finansijskih izveštaja značajan zadatak organizacione jedinice interne revizije banaka $u$ RS.

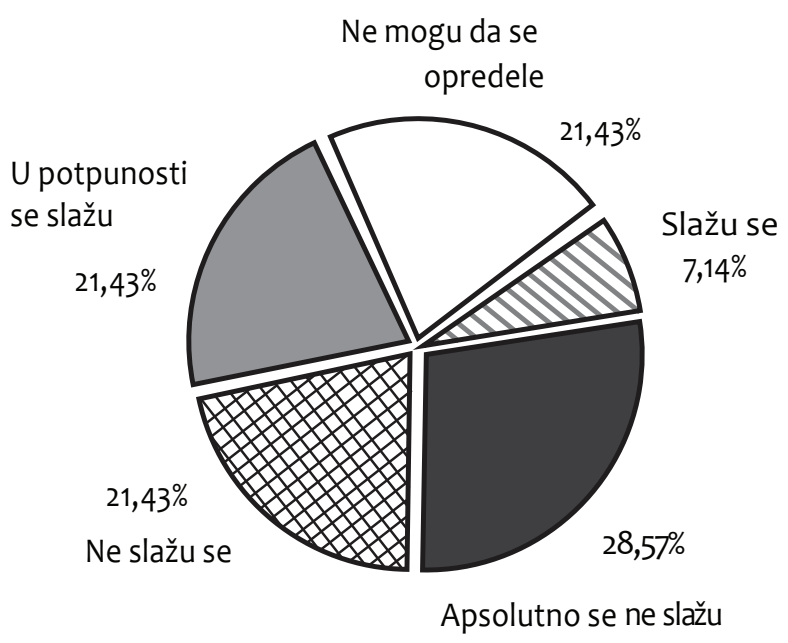

Grafikon 6 Blagovremeno sastavljanje kvalitetnih finansijskih izveštaja

Izvor: Autor, prema podacima iz Ankete

Tri banke, tj. 21,43\% ispitanih, u potpunosti se složilo da je blagovremeno sastavljanje kvalitetnih finansijskih izveštaja zadatak interne revizije i dali su ocenu 5; jedna banka, tj. 7,14\% ispitanih, dala je ocenu 4 , što znači da se slaže sa tim; tri banke, tj. 21,43\% ispitanih, nije moglo da se opredeli da li je to zadatak interne revizije i dali su ocenu 3; tri banke, tj. 21,43\% ispitanih, nije se složilo da je to zadatak interne revizije i dali su ocenu 2; četiri banke, tj. 28,57\% ispitanih, apsolutno nije se složilo da je to zadatak interne revizije i dali su ocenu 1.

$\mathrm{Na}$ Grafikonu 7 prikazano je kako su anketirane banke odgovarale na pitanje da li je dodavanje vrednosti akcijama vlasnika značajan zadatak unutrašnje revizije banke. 


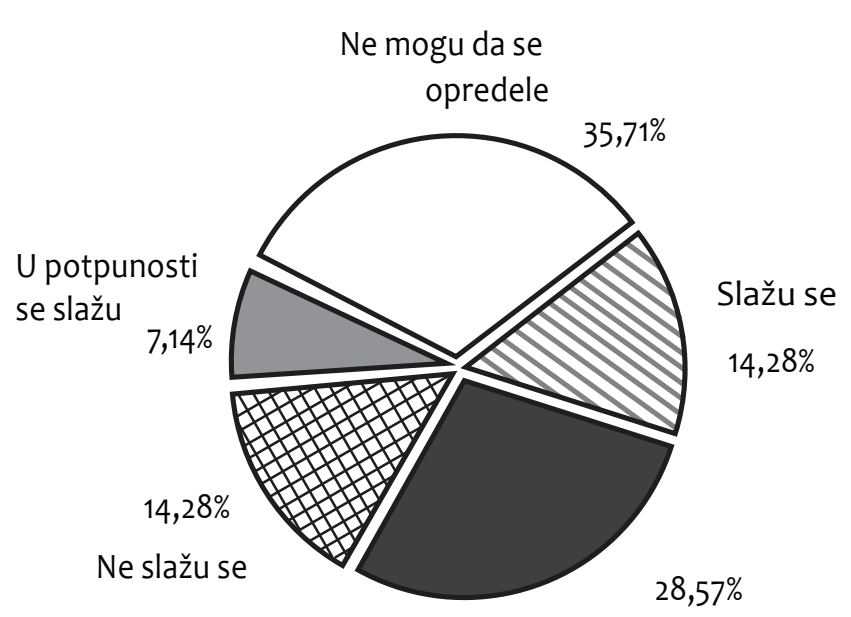

Apsolutno se ne slažu

Grafikon 7 Dodavanje vrednosti akcijama vlasnika

Izvor: Autor, prema podacima iz Ankete

Jedna banka, tj. 7,14\% ispitanih, u potpunosti se složila da je dodavanje vrednosti akcijama vlasnika zadatak interne revizije i dala je ocenu 5; dve banke, tj. 14,28\% ispitanih, dale su ocenu 4 , što znači da se slažu sa tim; pet banaka, tj. 35,71\% ispitanih, nije moglo da se opredeli da li je to zadatak interne revizije i dali su ocenu 3; dve banke, tj. 14,28\% ispitanih, nisu se složile da je to zadatak interne revizije i dale su ocenu 2; četiri banke, tj. 28,57\% ispitanih, apsolutno se ne slažu sa tim da je to zadatak interne revizije i dale su ocenu 1.

\section{ZAKLJUČAK}

Sprovedenim istraživanjem su dokazane sve tri postavljene istraživačke hipoteze. Naime, veličina banke ne utiče na organizaciju i zadatke interne revizije, što znači da postoji homogenost posmatrane populacije.

Razvoj interne revizije kao instrumenta poslovnog odlučivanja posledica je turbulentnih i složenih uslova poslovanja današnjice. U uslovima brzog razvoja tehnike, tehnologije, rastuće konkurencije, globalizacije, diverzifikacije i decentralizacije banaka načini odlučivanja se bitno menjaju. To posebno dovodi do naglašene uloge i značaja planiranja, organizovanja i kontrole na svim hijerarhijskim nivoima.

Na bazi sprovedenog upitnika i raznolikosti odgovora na postavljena pitanja možemo zaključiti da interna revizija u bankama u RS još uvek ima nejasan kontekst. Svetska iskustva nisu bolja i govore da oko $73 \%$ usluga interne revizije postoje manje od 20 godina, pa se tako može objasniti zašto veliki broj banaka nije imao dovoljno vremena da se prilagodi zadacima interne revizije $\mathrm{i}$ da ih potpuno razume. Anketa koja je sprovedena na uzorku od 14 banaka u Republici Srbiji, pokazala je sledeće:

- u Republici Srbiji dominiraju strane banke (64\%);

- anketirano je najviše centrala (54\%), filijala (39\%) i ekspozitura (7\%);

- banka Intesa je najveća banka u Republici Srbiji po najvećem broju kriterijuma;

- interna revizija u anketiranim bankama je ravnomerno organizovana kao sektor $(43 \%)$, služba $(21 \%)$ ili odeljenje (36\%), što nije uvek u korelaciji sa veličinom banaka;

- interna revizija je podređena upravnom odboru smatra 29\% banaka u RS; i

- primarni zadatak u posmatranim bankama je ocena usklađenosti poslovanja sa Zakonom, politikama, poslovnom praksom i postupcima menadžmenta.

$\mathrm{Na}$ osnovu zaključaka dobijenih empirijskim istraživanjem mogu se formirati predlozi za unapređenje funkcije interne revizije $\mathrm{u}$ bankama $\mathrm{u}$ RS. Zadatak interne revizije trebalo bi biti istraživanje planova, programa, politika i postupaka kako bi se što objektivnije moglo oceniti njihovo izvršenje na svim nivoima. Takođe, zadatak interne revizije treba da uključi i kritičko praćenje ostvarivanja ukupnog plana i pojedinačnih planova, informisanje menadžmenta o odstupanjima od standarda i planiranih ciljeva, davanje preporuka i saveta $\mathrm{u}$ vezi sa mogućim korektivnim akcijama kojima bi se uočena odstupanja otklonila. Interna revizija treba sve više da se usmerava na anticipiranje mogućih rizika u pojedinim područjima poslovanja banke i na savetovanje menadžmenta o mogućnostima upravljanja brojnim rizicima u smislu oblikovanja i nadziranja odgovarajućeg sistema internih kontrola 
kojima će se rizici efikasno smanjivati. Stoga predmet ispitivanja internog revizora treba da postane celokupno poslovanje okrenuto budućnosti. Stepen ostvarenja novih zadataka interne revizije, uspešnost implementacije uslovljenih politikama i postupcima u budućoj praksi poslovanja banaka u RS, može biti inspirativan za buduća istraživanja funkcionisanja ovog izuzetno značajnog područja poslovanja banaka.

$\mathrm{Na}$ osnovu sprovedenog istraživanja $\mathrm{u}$ bankama u Republici Srbiji, može se zaključiti da je interna revizija organizovana kao samostalna organizaciona jedinica i to kao sektor, $u$ najvećem broju ispitanih banaka. Odlukom o osnovnim principima organizacije i rada interne revizije banke propisano je da interna revizija treba da bude organizovana kao samostalna organizaciona jedinica, jer na taj način interna revizija kontinuirano prati, proverava i unapređuje sistem rada u banci, vrši identifikaciju rizika kojima je banka izložena ili može biti izložena, ocenjuje uspostavljeni sistem internih kontrola, izdaje odgovarajuće preporuke za otklanjanje nepravilnosti. Time se postiže osnovni cilj interne revizije u bankama, a to je da obezbedi zaštitu boniteta banke i realno iskaže njen finansijski rezultat.

Istraživanje je pokazalo da je interna revizija $u$ bankama u Republici Srbiji podređena upravnom odboru i menadžmentu banke, tj. tako je kod najvećeg broja ispitanih banaka. Pošto u svetu, u savremenim uslovima poslovanja, vlada mišljenje da je najbolje da interna revizija bude podređena najvišem rukovodstvu, u našoj zemlji banke delimično ispunjavaju taj zahtev, jer pored podređenosti upravnom odboru, $u$ našim bankama postoji i podređenost menadžmentu banke. Kod manjeg broja ispitanih banaka postoji podređenost interne revizije izvršnom odboru i odboru za reviziju. Podređenost interne revizije skupštini akcionara banke kao najvišem rukovodstvu postoji kod veoma malog broja banaka u našoj zemlji. Radi ispunjavanja svetskog nivoa poslovanja mora se na nivou cele zemlje, u svim bankama poboljšati sistem podređenosti interne revizije komitetu za reviziju, posebno u velikim bankama.

Što se tiče zadataka interne revizije, banke u našoj zemlji smatraju da je to otkrivanje i sprečavanje grešaka i nelegalnih radnji, kao i ocena usklađenosti poslovanja sa zakonom, politikama i poslovnom praksom banke. Ostali zadaci: ocena uspešnosti računovodstvenog sistema i sistema unutrašnjih kontrola, blagovremeno sastavljanje kvalitetnih finansijskih izveštaja i dodavanje vrednosti akcijama su dobili niže ocene od strane naših banaka. To znači da banke smatraju da to nisu toliko bitni zadaci interne revizije, jer nisu dovoljno upoznate sa njima, ali u svetu su ti zadaci veoma razvijeni pa se kod nas mora raditi i na njihovom razumevanju i na edukaciji. Može se zaključiti da je interna revizija u stvari savetnik mendžmenta banke i da je posao interne revizije odgovoran jer se odnosi na davanje saveta i predloga i ne može mu se oduzeti nezavisnost.

Interesantno je naglasiti da će interna revizija obuhvatati sve više novih i raznovrsnih domena i to: reviziju kvaliteta, reviziju životne okoline, reviziju preduzetništva, menadžmenta, strategije i sl. Jedno je sigurno - interna revizija je postala interni savetnik koji nema represivni već zaštitni karakter. Interna revizija je univerzalna delatnost koja se može primeniti u svim bankama i u svim segmentima jedne banke. Dakle, interna revizija je funkcija koja kontroliše sve ostale funkcije.

\section{REFERENCE}

Allen, D., Sneathen D., \& Tim, K. (2007). The Effects of Fraud and Going-concern Risk on Auditors' Assessments of the Risk of Material Misstatement and Resulting Audit Procedures, International Journal of Auditing, 11(3), 149-163.

Boynton W., \& Johnson, R. (2006). Modern Auditing. The $8^{\text {th }}$ edition. New Jersey, NJ: John Wiley \& Sons, Inc.

Gramling, A., Rittenberg, L., \& Johnstone, K. (2012). Auditing. The $8^{\text {th }}$ edition. Canada: South-Western.

Krogstad, J., Ridley, A., \& Ritterberg, L. (1999). Where are we going? Internal Auditor, 56(5), 26-33.

Kukoleča, S. (1995). Osnovi ekonomije. Beograd, Srbija: Savremena administracija.

Lee, T., \& Alan, P. (1984). The Nature, Scope and Qualities of Auditing. In S. Carsberg (Ed.), Current Issues in Auditing, Philip Alan.

Ljubisavljević, S. (2000). Uloga eksternog revizora u okruženju. Kragujevac, Srbija: Ekonomski fakultet. 
Meigs, W., Wittington, O., \& Pany, K. (1988). Principles of Auditing. McGraw-Hill, Irwin.

Milojević, D. (2006). Revizija finansijskih izveštaja. Beograd, Srbija: FTB, BBA.

Milosavljević, S., \& Radosavljević, I. (2003). Osnovi metodologije političkih nauka. Beograd, Srbija: Službeni glasnik.

Munro, L., \& Stewart, J. (2011). Exsternal auditors' reliance on internal auditing: further evidence. Managerial Auditing Journal, 26(6), 464-481.

Odluka o osnovnim principima organizacije i rada interne revizije banke i druge finansijske organizacije. (2002). Službeni list SRJ 39.

Pickett, S. (1997). Profesionalna praksa interne revizije. Beograd, Srbija: Savez računovođa i revizora Srbije.

Pickett, S. (2011). The Essential Guide to Internal Auditing. London, UK: John Wiley \& Sons.

Poznanić, V. (2011). Uloga odbora za reviziju u korporativnom upravljanju. Revizor, 13(53), 10-24.

Raschenberger, M. (1929). Internationales Revision und Treuhandwesen. Wien.
Renard, J. (1997). Theorie et pratique de l'audit interne. Paris, Les editions d'organisation.

Rossel, J. (2007). The Internal Auditing Pocket Guide: Preparing, Performing, Reporting and Follow-up. The $2^{\text {nd }}$ Edition. Milwaukee, Wisconsin: American Society for Quality Press, 4, 10-25.

Sarens, G., \& De Beelde, I. (2006). The Relationship between Internal Audit and Senior Management: A Qualitative Analysis of Expectations and Perceptions. International Journal of Auditing, 10(3), 219-241.

Soh, D., \& Martinov-Bennie, N. (2011). The internal audit function: Perceptions of internal audit roles, effectiveness and evaluation. Managerial Auditing Journal, 26(7), 605-622.

Spahić, N. (2008). Izveštaj interne revizije. Revizor, 10(41), 5-19.

Stuart, I. (2012). Auditing and Assurance Services: An Applied Approach. New York, NY: McGraw-Hill, Irwin.

Zakon o bankama i drugim finansijskim organizacijama (2005), Službeni glasnik RS 107 i izmene ovog zakona, Službeni glasnik RS 91/2010.

\section{Primljeno 11. februara 2013, nakon revizije, prihvaćeno za publikovanje 19. aprila 2013.}

Snežana Ljubisavljević je vanredni profesor na Ekonomskom fakultetu Univerziteta u Kragujevcu. Doktorirala je u oblasti poslovne ekonomije - računovodstva i revizije, na Ekonomskom fakultetu Univerziteta u Beogradu. Ključne oblasti naučnog interesovanja i rada su specifična područja revizije finansijskih izveštaja, interna kontrola i revizija, i računovodstvo finansijskih organizacija. 


\title{
ORGANIZATION AND TASKS OF INTERNAL AUDIT IN DOMESTIC AND FOREIGN BANKS IN SERBIA
}

\author{
Snezana Ljubisavljevic \\ Faculty of Economics, University of Kragujevac, Kragujevac, Serbia
}

The paper attempts to determine the achieved level of internal audit development in Serbian banks, based on the referent Anglo-Saxon literature and practice. Empirical research has included the sample of 14 banks in the Republic of Serbia, out of the 32 banks, with the aim to seek the methods of organizing internal audit and its tasks within them. The subject of this study is to determine how managers and employees in senior positions in the bank understand the role and importance of internal audit. Based on the questionnaire responses, the aim of the paper is to make suggestions for the improvement of this important bank function. The research results indicate that the bank size does not affect the organization methods, responsibility, and tasks of the internal audit of the bank. The achieved level of internal audit development in financial institutions is at a much higher level compared to economic entities, but in many areas, it is behind the internal audit of developed countries.

Keywords: internal audit, organization, tasks, domestic banks, foreign banks

JEL Classification: M42, G21, H83 